THEME SECTION: REVIEW The following text is a contribution to Inter-Research Symposium 1 'Satellite Tracking for the Conservation of Migratory Vertebrates' held in Myrtle Beach, SC, USA in February 2007

\title{
Satellite tracking of sea turtles: Where have we been and where do we go next?
}

\author{
B. J. Godley ${ }^{1, *}$, J. M. Blumenthal ${ }^{1,2}$, A. C. Broderick ${ }^{1}$, M. S. Coyne $^{1,3}$, \\ M. H. Godfrey ${ }^{4}$, L. A. Hawkes ${ }^{1}$, M. J. Witt ${ }^{1}$ \\ ${ }^{1}$ Marine Turtle Research Group, Centre for Ecology and Conservation, School of Biosciences, University of Exeter, \\ Cornwall Campus, Penryn TR10 9EZ, UK \\ ${ }^{2}$ Department of Environment, PO Box 486, Grand Cayman KY1-1106, Cayman Islands \\ ${ }^{3}$ SEATURTLE.org, 1 Southampton Place, Durham, North Carolina 27705, USA \\ ${ }^{4}$ North Carolina Wildlife Resources Commission, 1507 Ann Street, Beaufort, North Carolina 28516, USA
}

\begin{abstract}
The use of satellite tracking for the fundamental and applied study of marine turtles began in the 1980s but has undergone rapid growth in recent years. To provide a background against which to judge the past success and future directions of these research efforts we carried out a comprehensive review of over 130 scientific papers on the use of this technique in this taxon. We show how satellite tracking has changed over time as well as outlining biases in spatial, species and lifestage coverage. Descriptions of migration routes and other habitats have offered novel insights into the basic life history patterns of some species, highlighted focal areas for conservation and reinforced the multi-national nature of the stakeholders of many populations. In foraging areas, knowledge is growing as to how animals move within dynamic seascapes, thus facilitating our understanding of 3-dimensional habitat use and seasonal patterns of behaviour. More experimental approaches have elucidated navigational capabilities and post-release survival following fisheries interaction and long-term captivity. In addition, through the Internet and other media, satellite tracking appears to have been effective in engaging public attention in many countries. Finally, we discuss why the use of the technique has increased so markedly over time and point out key areas of concern that we feel should be addressed by the community of researchers and donors who focus on sea turtles.
\end{abstract}

KEY WORDS: Sea turtles $\cdot$ Satellite tracking $\cdot$ Migration $\cdot$ Conservation $\cdot$ Navigation $\cdot$ Tagging reflex Resale or republication not permitted without written consent of the publisher

\section{OVERVIEW}

Many species of marine megavertebrates are of profound conservation concern as the result of a range of past and ongoing impacts such as direct exploitation (Roman \& Palumbi 2003, Baum \& Myers 2004), indirect take in fisheries (NRC 1990, Hall et al. 2000) and habitat degradation (e.g. Gardner et al. 2003). For effective mitigation of direct threats, there is an acute need to understand how these animals use dynamic seascapes. The elaboration of an ever increasing array of tracking technologies has transformed this field of study (Block
2005, Block et al. 2005), with satellite tracking using the Argos system (Argos 1996) having become particularly prevalent in recent decades (Gillespie 2001).

Marine turtle life histories typically span large temporal and spatial scales (Musick \& Limpus 1997, Plotkin 2003). Researchers have now extensively utilized satellite tracking to yield a number of insights into the spatial ecology of this group at a range of scales. Recent highlights include demonstrating transPacific migration in leatherback turtles Dermochelys coriacea (Benson et al. 2007a), showing high levels of fidelity to foraging areas across multiple years in green 
turtles Chelonia mydas, loggerhead turtles Caretta caretta and Kemp's ridley turtles Lepidochelys kempii (Broderick et al. 2007, Shaver \& Rubio 2008, this Theme Section [TS]), recording juvenile hibernation of loggerhead turtles (Hochscheid et al. 2005), unlocking the adult life histories of the more enigmatic species (leatherback turtles: James et al. 2005a,b,c; hawksbill turtles Eretmochelys imbricata: van Dam et al. 2008, this TS), as well as questioning some of the established life-history models for other better studied species (loggerhead turtles: Hatase et al. 2002b, Hawkes et al. 2006; green turtles: Hatase et al. 2006, Seminoff et al. 2008, this TS).

There are a number of reasons why workers have sought to track turtles using the Argos system. Firstly, given its global coverage, satellite tracking allows us to follow turtles in near real time and find out what routes they take, no matter how far they go. This does not mean to devalue the seminal work of the pioneering turtle taggers (e.g. Hendrickson 1958, Balazs 1976, Carr et al. 1978, Limpus et al. 1992) who discovered a great deal about turtle dispersion using modified farm animal markers backed up by thousands of painstaking hours on the beach and years of patiently waiting for results. The main problems with using flipper tags to unlock spatial movements are that large numbers must be deployed to ensure sufficient recaptures and biases are present in the likelihood of recapture and reporting (Godley et al. 2003b). Although animals can be tracked with flipper tags over long durations, possibly up to decades (Limpus et al. 1992, C. J. Limpus pers. comm.), little is known of the intervening route and speed. In contrast, satellite tagging, when carried out effectively, yields significant information regarding each study individual, including routes and speeds and, above all, this information can be gathered quickly, albeit for a typical maximum duration of several months to a few years, with a fiscally dictated sample size.

In order to provide a detailed background against which to judge the past success and future directions of such research efforts, we carried out a comprehensive review of $>130$ peer-reviewed research publications that have used this technique in this taxon (Appendix 1; see also reviews by Papi \& Luschi 1996, Luschi et al. 2003a, 2006, Plotkin 2003, Morreale \& Standora 2005).

\section{THE RISE OF THE SATELLITE TAG}

The first published results of successful satellite tracking of sea turtles were of post-nesting loggerhead turtles in the USA (Stoneburner 1982, Timko \& Kolz 1982) followed by that of a single leatherback turtle tracked after nesting in French Guiana (DuronDufrenne 1987). Following a gap of several years, results were published on additional loggerhead and green turtles tracked in Greece (Hays et al. 1991) and Japan (Baba et al. 1992). These latter publications marked the start of an exponential rise (Fig. 1a, Appendix 1), with as many as 24 scientific papers utilising the technique in 2006 alone (at time of writing, this total has already been surpassed for 2007). The
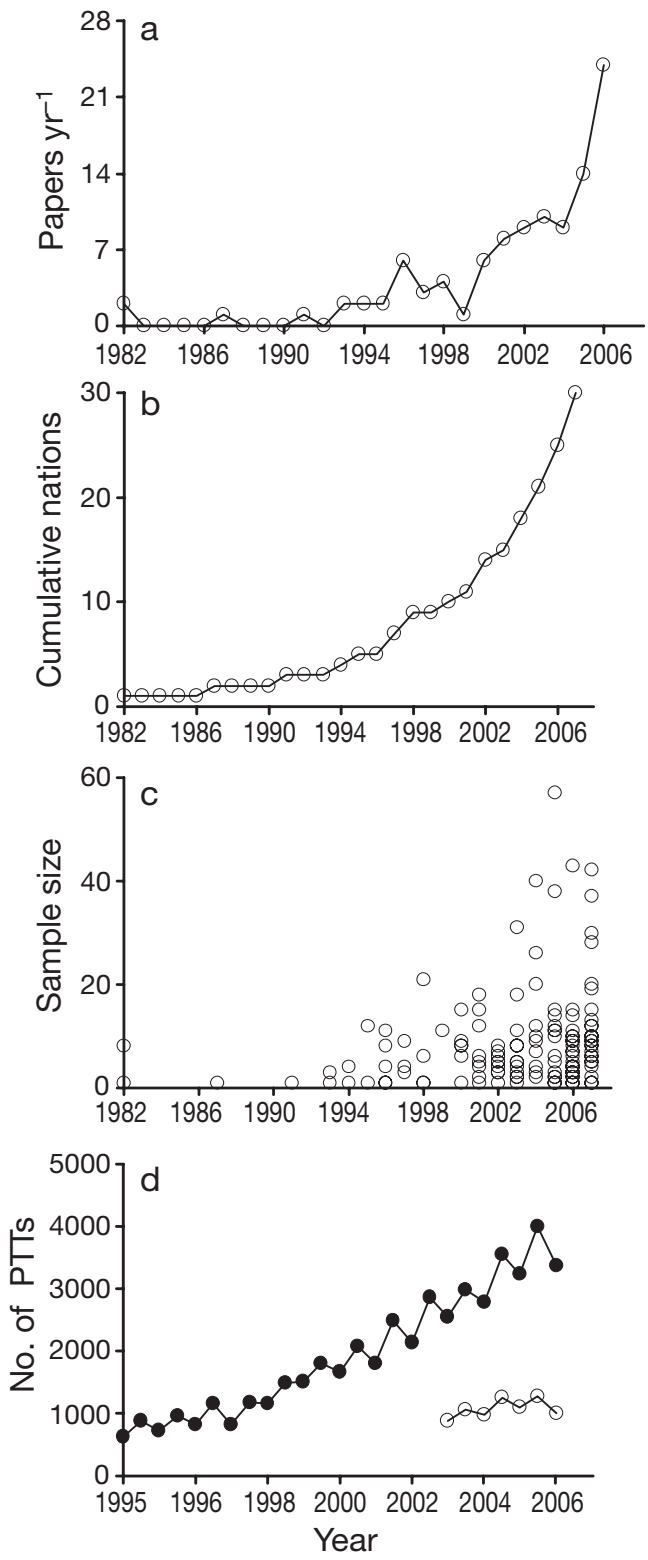

Fig. 1. Growth of satellite tracking in sea turtles. (a) Number of peer-reviewed papers involving satellite tracking published per year (1982-2006). (b) Cumulative total number of geopolitical units as deployment sites of satellite tracking in the published literature (1982-2007). (c) Temporal pattern in species-specific sample size in peer-reviewed publications (1982-2007). (d) Temporal pattern in number of active platforms for marine animals in each half year (๑: 1995-2006) and marine turtles (O: 2004-2006). PTT: platform terminal transmitter. Note that Panels $(\mathrm{a}-\mathrm{c})$ have a longer timescale than $(\mathrm{d})$ 
number of peer-reviewed publications, however, does not truly reflect how prolific the use of this technique has become for sea turtles. Further insight can be obtained from data gathered by CLS, the company that operates the Argos system. Tags recorded as being deployed on marine animals (fish, turtles, pinnipeds and cetaceans; excluding seabirds or archival fish tags) make up approximately one third of tags tracking animals (Fig. 1d). Of these marine animal deployments, since 2004, the 7 species of sea turtles have accounted for approximately $20 \%$ of the total (mean number of active sea turtle platforms per $6 \mathrm{mo}$ period $=252 \pm$ 68 (SD), range 140-355; Philippe Gros, CLS, pers. comm.). It should be noted that some tags may have been deployed multiple times and/or on species for which they were not initially intended. These numbers are, however, likely to be indicative.

\section{Biases inherent in work to date}

The number of countries of deployment of these published studies has also grown (Fig. 1b) but significant geographic biases remain. By the time of writing, publications reviewed had included transmitters deployed in only 30 geopolitical units, with an uneven distribution across the globe. (Atlantic Ocean: Western $35 \%$, Central 9\%, Eastern 4\%; Mediterranean 11\%; Indian Ocean $15 \%$; Pacific Ocean: Western 16\%, Central 1\%, Eastern 14\%; Appendix 1; NB some papers provide data on more than one species/ocean basin. Overall species-specific datasets published: $\mathrm{n}=141$ ). Much of this bias is likely related to differential funding for research among regions but is one that is gradually being addressed, partly as a result of strategic international funding by intergovernmental organisations and governments/non-governmental organisations in wealthier nations.

Perhaps more profound, however, are the species and life stage biases. To date, $82 \%$ of studies have featured only 3 species (Appendix 1: loggerhead turtle: $\mathrm{n}=38$; green turtle: $\mathrm{n}=39$; and leatherback turtle: $\mathrm{n}=39$ ) with much less effort expended thus far on 3 other species (Appendix 1: olive ridley Lepidochelys olivacea $\mathrm{n}=12$; Kemp's ridley turtle $n=8$; hawksbill turtle $n=6$ ). Finally, although there are no publications as yet on the flatback turtle Natator depressus, studies are underway (K. Pendoley pers. comm., S. Whiting pers. comm.). Given the ease of access at the rookery and the fact that their relatively large size is more conducive to device attachment, it is perhaps not so surprising that over $75 \%$ of the published tracking studies have featured adult females. Even within this life stage, however, there may be some bias in selecting individuals (see next subsection).

\section{Tracking females at the nesting grounds}

Although adult sea turtles are perhaps most vulnerable on the nesting beach, these habitats are relatively well known and, given the will and the means, solutions to many threats are relatively more tractable than those at sea. The inwater breeding/internesting habitat is also a point of relatively high risk where dense aggregations of adult turtles are found in limited areas during the periods prior to and between multiple clutch depositions. It is, therefore, of interest to define these areas and the level of nest site fidelity shown by individuals during multiple breeding attempts within the same season. However, the internesting habitat is also one where transmitters might fail as a result of mating, internesting resting behaviour e.g. under rocky ledges, nesting behaviour including sand excavation and terrestrial locomotion, or increased fisheries risk (Georges et al. 2007, Hays et al. 2007, Fossette et al. 2008, this TS) and many authors, ourselves included, have often taken the safer option and deployed transmitters in the latter part of nesting seasons to increase the likelihood of imminent departure, transmitter survival and thus successful tracking of migration (e.g. Luschi et al. 1998, Hays et al. 2002, 2004c, Godley et al. 2002). As well as having the potential to introduce artefacts into the ecological patterns of post-nesting movements described (e.g. if all individuals at the breeding colony late in the season had travelled from farther away), choosing individuals nesting at the end of the season tells us very little about space use prior to post-reproductive migrations. Satellite tracking studies have, however, whether by serendipitous coverage or design, still afforded a significant body of knowledge regarding behaviour in the internesting period.

Leatherback turtles have been shown to use extensive areas between successive nesting activities (Eckert 2006, Eckert et al. 2006, Georges et al. 2007, Hitipeuw et al. 2007). Although this usually only encompasses waters of the continental shelf, movements can be up to several hundred kilometres and encompass nesting at various beaches across different geopolitical units (Keinath \& Musick 1993). It is clear that the magnitude of spatial use in this species poses a significant impediment to designing effective marine protected areas or other mitigation measures for threatened breeding colonies (Witt et al. in press).

For some hardshell sea turtles, females typically remain within the vicinity of the nesting beach in the internesting period (loggerhead turtles: Stoneburner 1982, Godley et al. 2003a; green turtles: Hays et al. 1999, Craig et al. 2004, Troëng et al. 2005b, Fuller et al. 2008, this TS; hawksbill turtles: Troëng et al. 2005a, Whiting et al. 2006; Kemp's ridley turtles: Seney \& 
Landry 2008, this TS, Shaver \& Rubio 2008). As a result of gathering extensive, spatially explicit internesting data in the vicinity of the rookery, Zbinden et al. (2007) were able to make a series of recommendations regarding the management of the Marine Park at Zakynthos, Greece.

Exceptions to the rule of staying nearby the nesting sites have been found, however. Some loggerhead and green turtles have undertaken oceanic loops during the internesting period (Blumenthal et al. 2006). In hawksbill turtles, subsequent nesting in the Dominican Republic was thought to have been described in 1 out of 7 females tracked from Puerto Rico (van Dam et al. 2008). Olive ridley turtles in Australia moved offshore from the nesting site (McMahon et al. 2007), remaining in neritic waters (Whiting et al. 2007). Earlier studies of this species in Costa Rica (Plotkin et al. 1995) did not receive sufficient locations to reconstruct tracks, although the turtles seemed to stay in the vicinity but may, in some cases, have moved offshore into oceanic habitat between breeding attempts.

\section{Post-nesting movements of adult females}

Recent reviews of long distance movements in sea turtles (Luschi et al. 2003b, Plotkin 2003) suggested that, with exceptions, there were 2 main patterns of movement: Firstly, departure from the breeding site, swimming directly towards a fixed feeding area, generally in the neritic (hereafter 'Type A') and secondly, departure to oceanic habitats followed by wandering movements, often over great distance ('Type B'). Through satellite tracking, ever-increasing insight has been gathered for 6 of the 7 species of sea turtle in a relatively short period of time. This has allowed us to suggest a 4 point classification framework (Types A1 to A3, and Type B) to describe patterns in post-nesting movements in adult turtles. Although we follow the distinction between 'oceanic' and 'pelagic' as in Bolten (2003a), our classification framework for adult movement should not be confused with the 3-part classification of development pattern proposed by Bolten (2003b).

\section{Type A1 - oceanic and/or coastal movements to neritic foraging grounds}

All green turtle populations so far tracked have exhibited this pattern, at least in part, whether they nest on islands (e.g. Pacific: Cheng 2000, Craig et al. 2004, Yasuda et al. 2006; Atlantic: Luschi et al. 1998, Blumenthal et al. 2006; Mediterranean: Broderick et al. 2007) or the continental shelf (Kennett et al. 2004,
Troëng et al. 2005b). Routes are often relatively direct but can involve coastal sections that mean a greater migratory distance but perhaps afford interim foraging possibilities en route to preferred foraging areas (Cheng 2000, Godley et al. 2002) or may facilitate navigation (Hays et al. 2002).

Loggerhead turtles that nest on continental nesting beaches typically undertake coastal migrations to foraging grounds and in some populations appear to demonstrate long-term residency (e.g. Limpus \& Limpus 2001, Luschi et al. 2006, Broderick et al. 2007), whilst others undertake seasonal latitudinal shuttling (see Type A2 below). Some populations nesting on oceanic islands have demonstrated dichotomous behaviour with larger adult animals displaying Type A1 behaviour and smaller adult animals foraging pelagically generally in oceanic habitats (see Type B below).

Given some of the controversy that has surrounded the ecology and status of hawksbill turtles (Mrosovsky 1997, Meylan 1998) it is somewhat surprising that very few data have been published in only 4 studies of adult migrations to date. In the insular Caribbean (Horrocks et al. 2001, van Dam et al. 2008), individuals crossed oceanic areas and moved through other neritic areas to their final foraging grounds (Fig. 2a). In Costa Rica (Troëng et al. 2005a) and the Gulf of Carpentaria, Australia (Whiting et al. 2006) continentally nesting hawksbills moved along the coastal shelf to discrete foraging areas.

Recent studies of olive ridley turtles in Australia (McMahon et al. 2007, Whiting et al. 2007) have highlighted that although some turtles do live pelagically, others move through continental shelf waters to locations where they forage benthically, sometimes at rather greater depths than had previously been thought (McMahon et al. 2007). Post-nesting tracks of Kemp's ridley turtles took them through coastal waters, where they established coastal home ranges (Seney \& Landry 2008, Shaver \& Rubio 2008).

Type A2 - coastal shuttling between summer foraging and wintering sites

For turtles at temperate latitudes, seasonal oscillations in climate may mean that it is essential or beneficial to move to lower latitudes or other areas with higher water temperatures during the winter season. It should be noted that this is demonstrably the case for leatherback turtles within their Type B movements (Hays et al. 2006, James et al. 2005a, 2006b) but within the hardshell turtles in neritic habitats, this has only been shown in 2 species that are regularly found in temperate waters. It is the predominant strategy for loggerhead turtles in North America (Plotkin \& 

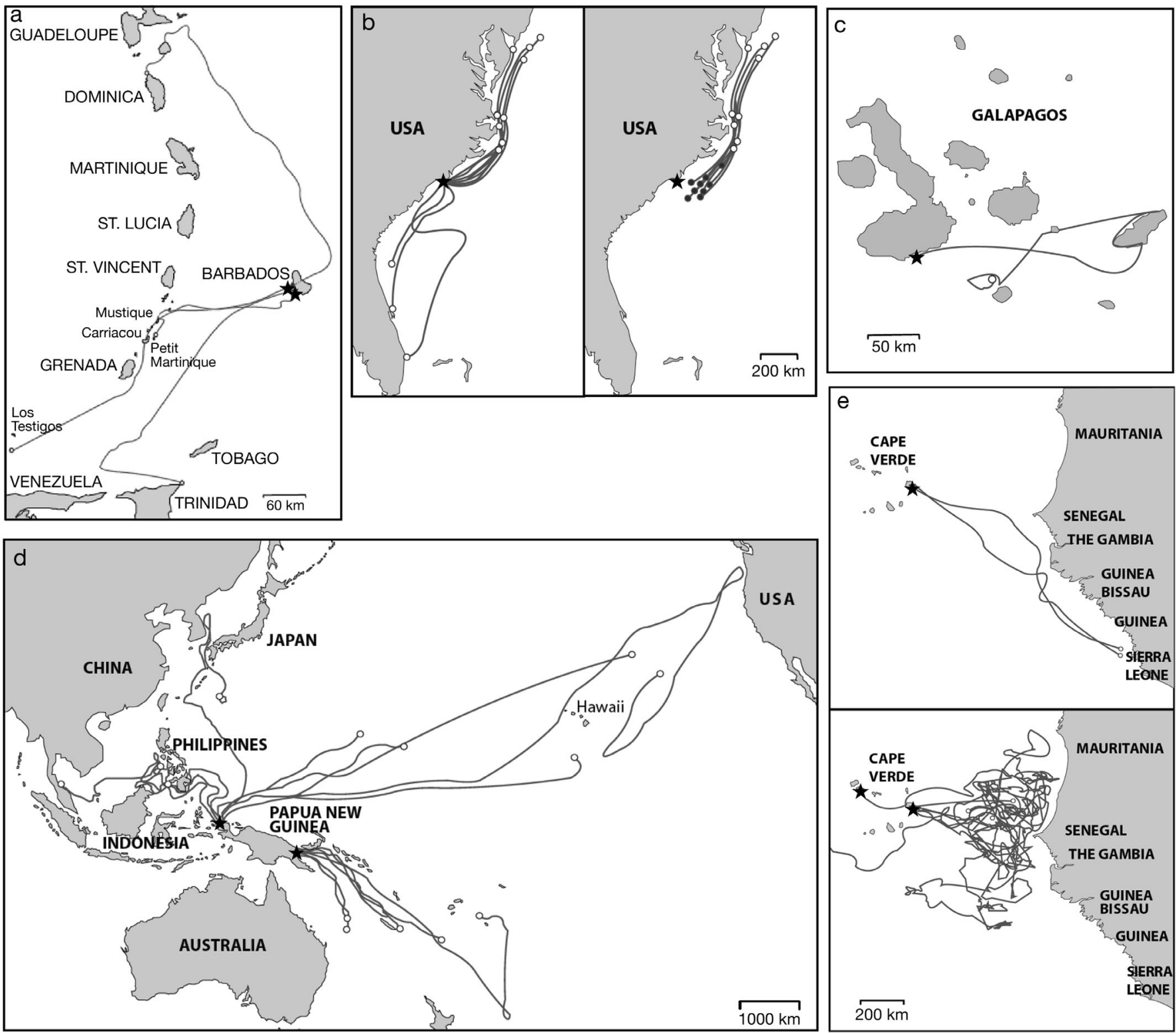

Fig. 2. Diversity of post-nesting dispersal patterns in adult female turtles. $\star$ : tagging location; O: last known location (except in b). (a) Type A1 - coastal and/or oceanic movements to neritic foraging grounds. Hawksbill turtles following nesting in Barbados (Horrocks et al. 2001; $\mathrm{n}=4$; courtesy of authors and Allen Press). (b) Type A2 - coastal shuttling between summer foraging and wintering sites. Loggerhead turtles following nesting at Bald Head Island, North Carolina, USA. Left panel: post nesting migration to summer/autumn foraging grounds $(O)$; right panel: southward autumn migration to overwintering grounds ( $)$ (Hawkes et al. 2007; $\mathrm{n}=9$ with an additional 3 staying resident in southern areas; courtesy of authors and Blackwell Publishing). (c) Type A3 - local residence. Short range movements of a female green turtle following nesting in Galapagos Islands, Ecuador (Seminoff et al. 2008; $\mathrm{n}=1$; courtesy of authors and Inter-Research Science Publishers). (d) Type B - pelagic living. Leatherback turtles following nesting in Indonesia and Papua New Guinea (Benson et al. 2007a, b; n = 28, courtesy of authors and Allen Press). (e) Mixed strategy (Type A1 and B) of loggerheads following nesting in Cape Verde (Hawkes et al. 2006; n = 9; 2 Type A1 and 7 Type B; courtesy of authors and Elsevier Publishing)

Spotila 2002, Morreale \& Standora 2005, Hawkes et al. 2007; our Fig. 2b). Although some Kemp's ridley turtles that have been tracked using satellite appear to undertake some form of seasonal shuttling (Morreale \& Standora 2005, Renaud \& Williams 2005, Gitschlag 1996), this does not seem to be a prevalent pattern among adult females tracked to date (Shaver \& Rubio 2008). It should be noted that although thermal conditions are not necessarily the proximate cue for such movements, it is likely that temperature and its ecological correlates will, in part, be the ultimate drivers of such behaviours. 
Type A3 - local residence

Satellite tracking has confirmed past flipper tagging results (Limpus et al. 1992, Green 1984) in that not all individual sea turtles are profoundly migratory, with some individuals staying in the neritic areas in the vicinity of the nesting colony, migrating only short distances. This has been demonstrated in green turtles in the Galapagos Islands (Seminoff et al. 2008; our Fig. 2c) and loggerhead turtles in the Mediterranean (Broderick et al. 2007), hawksbill turtles in Australia (Whiting et al. 2006) and Kemp's ridley turtles in USA (Shaver \& Rubio 2008). Definition of movements in this category is confounded by the difficulty posed by a lack of a clear threshold between Types A1 and A3. Although it is likely to be population-specific, a putative threshold would be the extent of normal internesting movement.

Type B — pelagic living

The leatherback turtle typifies the pelagic sea turtle, and adult females have been shown to undertake dramatic transoceanic movements. Much of their time is spent in oceanic habitats and, although neritic waters are often used (James et al. 2005c, Eckert et al. 2006), it is likely that they feed epipelagically (Hays et al. 2004b,c). In the eastern Pacific, females nesting in Costa Rica (Morreale et al. 1996) and Mexico (Eckert \& Sarti 1997) were subsequently tracked southwards across the equator into international waters and those of the Galapagos, Peru and Chile. Morreale et al. (1996) suggested the presence of an important migratory corridor, whilst Eckert \& Sarti (1997) raised concern that the coincidence of turtles in a global fishery hotspot may be causal in the declines in leatherbacks observed in the eastern Pacific. More recent tracking of stocks nesting in the Western Pacific has demonstrated that postnesting females undergo a variety of migration routes, including south into the South Pacific, east into coastal waters off North America, north into waters off Japan, and west into waters of the Philippines and Malaysia (Fig. 2d; Benson et al. 2007a,b). In the Atlantic, following seminal work with limited tracking duration (Duron-Dufrenne 1987, Keinath \& Musick 1993), more recent tracking has shown adult females from western Atlantic stocks nesting in French Guiana and Suriname (Ferraroli et al. 2004), Grenada (Hays et al. 2004c), the USA (Eckert et al. 2006) and Trinidad (Eckert 2006) disperse widely throughout the north Atlantic, often using the productive waters associated with the Gulf Stream. In the Indian Ocean, only turtles from South Africa have thus far been tracked (Hughes et al. 1998, Luschi et al. 2003c, 2006). These individuals have typically stayed in oceanic habitats undertaking convo- luted routes associated with strong current systems within $1000 \mathrm{~km}$ of the African continent in both the Indian and Atlantic Oceans.

Although it is generally felt that post-hatchlings and small juveniles of all sea turtle species except the flatback turtle use oceanic habitats (Carr 1987, Musick \& Limpus 1997, Bolten 2003a,b) it appears that adults of several hardshell species are also to be found in the open ocean. Limited studies of adult female olive ridley turtles suggest that many individuals move directly to oceanic areas following nesting (Plotkin et al. 1995, Plotkin 1998, Pandav \& Choudhury 2006) but mixed strategies may be involved (McMahon et al. 2007, Whiting et al. 2007) including some neritic habitat utilisation. Although loggerhead adults have long been thought to be primarily benthic feeders, description of migration routes by satellite tracking in some populations has demonstrated apparent size-related dichotomous migration strategies with smaller animals undertaking Type B lifestyles and larger individuals the more typical Type A1 (Hatase et al. 2002b, Hawkes et al. 2006). Additionally, Luschi et al. (2003b) showed that, following experimental displacement, adult loggerheads could live in the open ocean. The green turtle, long thought to be a near obligate herbivore and therefore tied to benthic habitats, has recently been tracked and observed showing behaviours highly suggestive of oceanic feeding after nesting in Japan (Hatase et al. 2006) and the Galapagos (Seminoff et al. 2008).

Finally, there appear to be some individuals who in the midst of, or prior to, a sequence of Type A1 coastal movements, undertake oceanic loops (green turtle: Troëng et al. 2005b, Cheng 2000; loggerhead turtle: Dodd \& Byles 2003, Hawkes et al. 2007). Based on the increasing records of this type of behaviour, the weight of evidence of prevalence and timing suggests that this might sometimes represent a form of facultative habitat switching, including change of feeding mode, rather than simply orientation behaviour (Papi et al. 1997).

\section{Unifying patterns}

As tracking studies increase in the number of populations covered and individuals tracked, a number of general patterns are becoming clear.

Firstly, patterns of dispersal in adults of every hardshell turtle population thus far studied appear to encompass only a relatively discrete part of an ocean basin, e.g. green turtles from Costa Rica (Troëng et al. 2005b) and hawksbill turtles from Puerto Rico (van Dam et al. 2008) appear confined to the Caribbean. Loggerhead turtles from the Cayman Islands (Blumenthal et al. 2006) and Cape Verde (Hawkes et al. 2006) 
were tracked only to their proximate region of the Atlantic. This was also true in studies of loggerhead turtles tracked from nesting sites in the USA, where further substructuring is apparent when multiple sites are compared (Plotkin \& Spotila 2002, Dodd \& Byles 2003, Hawkes et al. 2007). This informs the generalised life history model for hardshell turtles where hatchlings are thought to disperse at the level of oceanic gyres (Musick \& Limpus 1997). The first phase of hatchlings and small juveniles is an oceanic one; this is typically followed by settling out into one of a series of neritic foraging habitats. Upon maturation, adult turtles undertake cyclical reproductive migrations from the foraging ground to the rookery of origin (Bowen \& Karl 1997, Musick \& Limpus 1997). Molecular evidence (Bowen et al. 2004, Bolker et al. 2007) suggests subregional natal homing in larger juveniles that we suggest is mirrored by adult distribution patterns as demonstrated by tracking. Indeed, Nichols et al. (2000) and Cejudo et al. (2006) appear to illustrate homing to the natal region in animals following captivity.

Secondly, it is becoming clear that there can be a diversity of strategies used by individuals within populations. There is more behavioural plasticity in sea turtles than might previously have been imagined. Clear examples of mixed strategies include those demonstrated by loggerhead turtles nesting in Japan (Type A1/B; Hatase et al. 2002b), the USA (Type A1/A2/B; our Fig. 2b; Hawkes et al. 2007) and Cape Verde (Type A1/B; our Fig. 2e; Hawkes et al. 2006); green turtles in Japan (Type A1/B; Hatase et al. 2006) and Galapagos (Type A1/A3/B; Seminoff et al. 2008); olive ridley turtles nesting in Northern Australia (Type A1/B; Whiting et al. 2007). Perhaps less clear are the differences within Type B movement patterns made by leatherbacks in the Western Atlantic (Ferraroli et al. 2004, Hays et al. 2004b, Eckert 2006, Eckert et al. 2006). Although there may be a degree of subregional fidelity shown by individuals to areas such as north, northeast or tropical Atlantic (James et al. 2005b, Hays et al. 2006), leatherbacks appear to generally disperse widely across most of the ocean basin but have not yet been tracked across the equator. Time and additional studies with larger sample sizes and of longer duration will further elaborate the ecological correlates of the different strategies used by females and also allow us to compare how closely these patterns of movement compare with conspecific adult males from the same populations.

\section{Tracking of adult females in the foraging grounds}

Description of behaviour of adults in foraging grounds is a fundamental part of most post-nesting tracking studies, although this is often achieved with limited success, typically with simple descriptions of the endpoint of tracks. This is particularly true when animals reach neritic locations and are thought to damage their transmitters, thus ending transmissions (loggerhead turtles: Stoneburner 1982, Godley et al. 2003a; green turtles: Luschi et al. 1998, Cheng 2000, Hays et al. 2002, Kennett et al. 2004). In addition, biofouling may also play a role in transmitter failure or intermittent function (Troëng et al. 2006, Broderick et al. 2007, Hays et al. 2007). Nevertheless, a growing body of studies can boast tracking datasets with durations in the foraging sites approaching a year or more, thereby yielding significant insights into aspects such as variable levels of foraging site fidelity among populations (e.g. loggerhead turtles: Blumenthal et al. 2006 vs. Broderick et al. 2007; green turtles: Troëng et al. 2005b, Broderick et al. 2007). Additionally, wintering patterns and Type A2 movements have now been described in great detail as a result of these long-term tracking studies (Hawkes et al. 2007). For leatherbacks, tremendous insights have been gained into foraging ground usage and seasonal shuttling (James et al. 2005b, Eckert et al. 2006, Hays et al. 2006, Seminoff \& Dutton 2007).

\section{Tracking migration to nesting grounds}

How sea turtles relocate their nesting grounds, particularly at remote insular locations, is one of the great mysteries of animal navigation, and experimentally testing hypotheses as to how they undertake their travels has become a focussed area of research (see 'Experimentation' below). So far, few transmitters deployed in the nesting grounds have lasted sufficiently long to have demonstrated return migrations, as this is typically a period in excess of 2 yr. Some individuals, however, have been tracked on their return migration after an interval of ca. 1 yr (loggerhead turtles to each of Cape Verde and Northern Cyprus: Godley et al. unpubl. data; Kemp's ridley turtles: Shaver \& Rubio 2008). Transmitters have been deployed in the foraging grounds and allowed females to be tracked to the nesting sites (loggerhead turtle: Limpus \& Limpus 2001; Kemp's ridley turtle: Renaud et al. 1996). In these cases, animals moved through coastal habitats to nesting sites in parallel with post-nesting migration strategy typical for each species.

\section{The under-represented majority}

What, however, of the under-represented majority of sea turtles i.e. the males and the far more numerous juveniles? Slowly the number of studies of adult 
males of 6 species has been building. With slight variations, it appears that one generality is that males display migration patterns broadly similar to those observed in adult female conspecifics and could be classified according to the 4 part classification detailed above. Reproductively active male olive ridley turtles tagged off Costa Rica dispersed to oceanic habitats upon the completion of reproduction (Plotkin et al. 1996) in a manner comparable with, albeit earlier than, females from the same site. An additional male olive ridley turtle collected in the Eastern Tropical Pacific was tracked for several months in the open ocean (Beavers \& Cassano 1996). Adult male green turtles at Ascension tracked using experimental transmitters with internal antennae (Hays et al. 2001c) provided enough data to suggest an extended mating period followed by a post-breeding migration pattern broadly similar to that previously described for conspecific females from the site (Luschi et al. 1998). The first published studies on the movements of male hawksbill turtles (van Dam et al. 2008) showed that although both sexes of the same population stayed within the same region, males travelled to more proximate foraging areas. Additionally, 2 males were recorded as returning to the breeding site within $1 \mathrm{yr}$ in comparison to the multi-year inter-breeding intervals typically demonstrated by conspecific females. Tracking of male Kemp's ridley turtles captured off the main nesting site for the species suggested that males did not disperse as far as conspecific females, generally residing in the vicinity of the nesting beach, and all stayed within Gulf of Mexico waters (Shaver et al. 2005). For the loggerhead turtle, limited tracking of males in the Pacific (Sakamoto et al. 1997, Hatase et al. 2002a) suggests the possibility of neritic and oceanic habitat use. Tracking of male leatherback turtles from high latitude foraging grounds (James et al. $2005 a, b, c)$ has demonstrated that males also travel south to breeding grounds across a similarly diffuse range of paths as females; possibly with a greater frequency. Once in the vicinity of breeding sites, they remain closer to shore than internesting females.

We also have a long way to go before we have an adequate understanding of juvenile movement patterns. All leatherbacks tracked to date have been adult or near adult sized, likely related to the relative lack of observations and captures of live juvenile leatherbacks in the wild (Eckert 2002). Despite physical size constraints there is a small but slowly building literature on the movements of juveniles of all hardshell species apart from the flatback turtle.

Within oceanic habitats, loggerhead turtles have so far received the most attention. Cardona et al. (2005) and Revelles et al. $(2007 \mathrm{a}, \mathrm{b})$ suggested that pelagic juvenile loggerheads in the Mediterranean generally avoided coastal areas and remained resident in relatively discrete oceanic areas for considerably longer than predicted by simulations based on passive drifting in ocean currents. Cejudo et al. (2006) showed near transatlantic movement of juveniles released at the Straits of Gibraltar. In the Pacific, Polovina et al. (2000, 2004, 2006) and Swimmer et al. $(2002,2006)$ have tracked relatively large numbers of juvenile loggerhead and olive ridley turtles, demonstrating clear inter-specific differences in habitat utilisation, association with specific oceanic features and active swimming against currents.

For large juvenile loggerhead turtles, movements have ranged from extensive (Bentivegna. 2002, Hochscheid et al. 2005) to relatively short range (Renaud \& Carpenter 1994) with individuals, although spending a majority of the time in the neritic, having the potential to move into oceanic habitats (Morreale \& Standora 2005, McClellan \& Read 2007). Tracking of juvenile green turtles (Godley et al. 2003b) demonstrated a range of behaviours from extreme site fidelity to movements over extended areas of coastline. Whiting \& Koch (2006) demonstrated the facultative shift of a juvenile hawksbill turtle in the Cocos Islands between habitats $>1000 \mathrm{~km}$ apart. Juvenile Kemp's ridley turtles have been shown to undertake seasonal migrations (Schmid \& Witzell 2006).

There is clearly room for much additional information to be gathered through further satellite tracking of males and immatures, particularly those juveniles in oceanic habitats where it is difficult to gather data by other means. Specifically, tracking of increased numbers of wild juveniles that are likely to be free from any anthropogenic influence is recommended, because although satellite tracking of rehabilitated or longline captured animals is a valid method of testing fates of these individuals, it is questionable how typical the behaviour of these animals is likely to be. Technology has yet to offer effective mechanisms of tracking individual hatchlings and other early life stages for extended periods, but in the terrestrial realm animals as small as dragonflies have been subject to radio tracking (Wikelski et al. 2006). Although aspirational, it seems plausible that technology may be developed that would allow tracking turtles in their first few years. This would seem a worthy target for future technological innovation.

\section{TECHNOLOGICAL ADVANCES}

As outlined above, a great deal has been uncovered from analysis of horizontal movement of marine turtles. These data have been significantly augmented by 2 major spheres of development: (1) the advancement of 
dive logging capability and (2) the integration of movements with oceanographic data.

\section{Time-space specific dive logging}

Rather than having to infer submergence patterns from Argos data (Hatase \& Sakamoto 2004) or simple dive summary data (Hays et al. 1999, Godley et al. 2002), incorporation of complex dive logging capabilities has now allowed individual dive profiles to be transmitted. Satellite-linked dive data are often sent in concatenated format (Fedak et al. 2001) and this system has recently been validated in sea turtles using traditional time depth recorders (Myers et al. 2006). Findings have shown how animals use the water column (Hays et al. 2004b,c, Sale et al. 2006, McMahon et al. 2007) and allowed elaboration of seasonal patterns in behaviour such as hibernation (Godley et al. 2002, Hochscheid et al. 2005, 2007, Broderick et al. 2007, Hawkes et al. 2007). Such data have allowed the suggestion of fisheries bycatch mitigation steps (Polovina et al. 2003). Linkage of dives with thermal profiles has facilitated postulation as to the thermal niche and possible future range under scenarios of climate change (James et al. 2006a, McMahon \& Hays 2006), and dive durations have even been used to infer field metabolic rates (Bradshaw et al. 2007).

\section{Integration with oceanography}

Inferences from movement patterns can be taken to a higher level once incorporation of oceanographic information starts to yield information as to how animals move within dynamic seascapes. Analysis of currents has given significant insights into oceanic movements of sea turtles (Polovina et al. 2000, Luschi et al. 2003a,c, Gaspar et al. 2006, Hawkes et al. 2006, 2007 , Sasamal \& Panigraphy 2006, Bentivegna et al. 2007, Revelles et al. 2007b). Inferred chlorophyll levels have shown how some populations are feeding in relation to oceanic productive zones (Polovina et al. 2000, Hawkes et al. 2006, Seminoff et al. 2008). For an integrated view including sea turtles and fisheries see Polovina et al. (2001). Interpretation of thermal conditions experienced by individual animals has facilitated a growing understanding of the physiological ecology of overwintering (Godley et al. 2002, Hochscheid et al. 2005, 2007, Broderick et al. 2007, Hawkes et al. 2007) and also the conditions that may trigger migration (Sherrill-Mix et al. in press) or be experienced during extended movements (Hays et al. 2001d, Seminoff et al. 2008). In a recent analysis of a long-term data series of gelatinous zooplankton across the North Atlantic it became clear that areas used by leatherback turtles tracked in previous published studies were among the clear hotspots of potential prey (Witt et al. 2007). A significant point in the consideration of past studies of movements and oceanographic variables is that comparisons have been largely qualitative; there is significant room for the development of techniques to allow more quantitative and dynamic comparisons. Further, the potentially exciting role of animal-borne sensors has been advocated within operational oceanography (Fedak 2004), and McMahon et al. (2005) have recently demonstrated that thermal data gathered by diving leatherbacks were reliable when compared with those gathered using the ARGO buoy system.

\section{ADDITIONAL AREAS OF ADVANCEMENT}

Several additional spheres of activity are worthy of highlighting as growing areas within the field.

\section{Experimentation}

Although the majority of studies to date have been descriptive, some studies, however, have taken a more experimental approach yielding significant insights into navigational capabilities of loggerhead (Papi et al. 1997, Luschi et al. 2003b) and green turtles (Papi et al. 1995, 2000, Luschi et al. 1996, 2001, 2007, Papi \& Luschi 1996, Åkesson et al. 2001, 2003, Hays et al. 2003a, Girard et al. 2006). Attaching high resolution time depth recorders to experimentally displaced individuals tracked by satellite facilitated the first detailed analysis of dive profiles during oceanic movement (Hays et al. 2001a).

\section{Inferring fates}

Hays et al. (2003b) reviewed a number of studies and data from previously unpublished tracks and suggested that satellite tracking could be used to infer capture in fisheries and thus generate an index of atsea survivorship, although this met with some controversy (Chaloupka et al. 2004b, Hays et al. 2004a). Others have used satellite tracking to describe the behaviour of animals immediately following bycatch (Swimmer et al. 2002, 2006, Chaloupka et al. 2004a, Revelles et al. 2007a,b), following rehabilitation and release (Bentivegna 2002, Cejudo et al. 2006) or after extended periods in captivity (Pelletier et al. 2003, Polovina et al. 2006). This includes the year-long, transpacific tracking of the captive-raised loggerhead turtle from Mexico to Japan (Nichols et al. 2000) and a 
comparison of wild adult females and those which had been headstarted (Shaver \& Rubio 2008).

\section{Sharing science}

There is tremendous public interest in marine vertebrates, especially taxa that exhibit spectacular migrations. Through near real-time tracking on the Internet, often associated with a media campaign, a number of organizations including our own have been highly successful in engaging large numbers of the public in turtle tracking projects (Coyne \& Godley 2005, Halpin et al. 2006). It is not possible to track the true impact of this interest, but as a value-added aspect of research efforts it must be considered positive.

\section{CATALYSIS}

There has been an acceleration of the use of satellite tracking of sea turtles, but how has this come about? We suggest that this development has been multi factorial. Over the last $25 \mathrm{yr}$, the technology has moved from an experimental to a far more operational phase. Transmitters and attachment methods have improved, with durations well in excess of a year no longer uncommon (Hays et al. 2006, Broderick et al. 2007, Hawkes et al. 2007, van Dam et al. 2008). Argos itself has improved, with the initiation of Argos service plus and improved global satellite coverage. Complemen- tary tools have also developed in parallel enabling easier handling and interpretation of data (Geographic Information Systems, remote sensing technologies and the Internet).

Although initially designed for turtle researchers, the Satellite Tracking and Analysis Tool (STAT; Coyne \& Godley 2005) has sought to bring all these electronic technologies together in an open access format for researchers of all taxa. Providing standard tools and formats, automated downloading and effective data preservation to maximize value from tracking data, STAT aims to foster collaboration and data sharing. This is especially powerful when combined with the open-access mapping suite Maptool (www.seaturtle. $\mathrm{org} / \mathrm{maptool} /$ ). The number of platforms stored within STAT continues to rise ( $\mathrm{n}=1976$, as of 1 Aug 2007) as do the taxa included: marine turtles, 7 spp.; sharks, 1 sp.; birds, $18 \mathrm{spp}$. (11 marine, 7 terrestrial); marine mammals, $6 \mathrm{spp}$. The global footprint of these endeavours has also increased with sea turtle deployments in 41 geopolitical units (Fig. 3). These include 25 nations not yet represented in the published literature.

Additional exciting innovations in the STAT portfolio are a new data-clearing house mechanism and geographically explicit viewing tools that allow managers to view all data within a geopolitical region from all data-sharing projects within the system (Coyne \& Godley 2007). Although the sample size in some studies has increased in recent years (Fig. 1c), given that $>68 \%$ of studies to date have involved species-specific sample sizes $<10$ and only $10 \%$ of studies were based

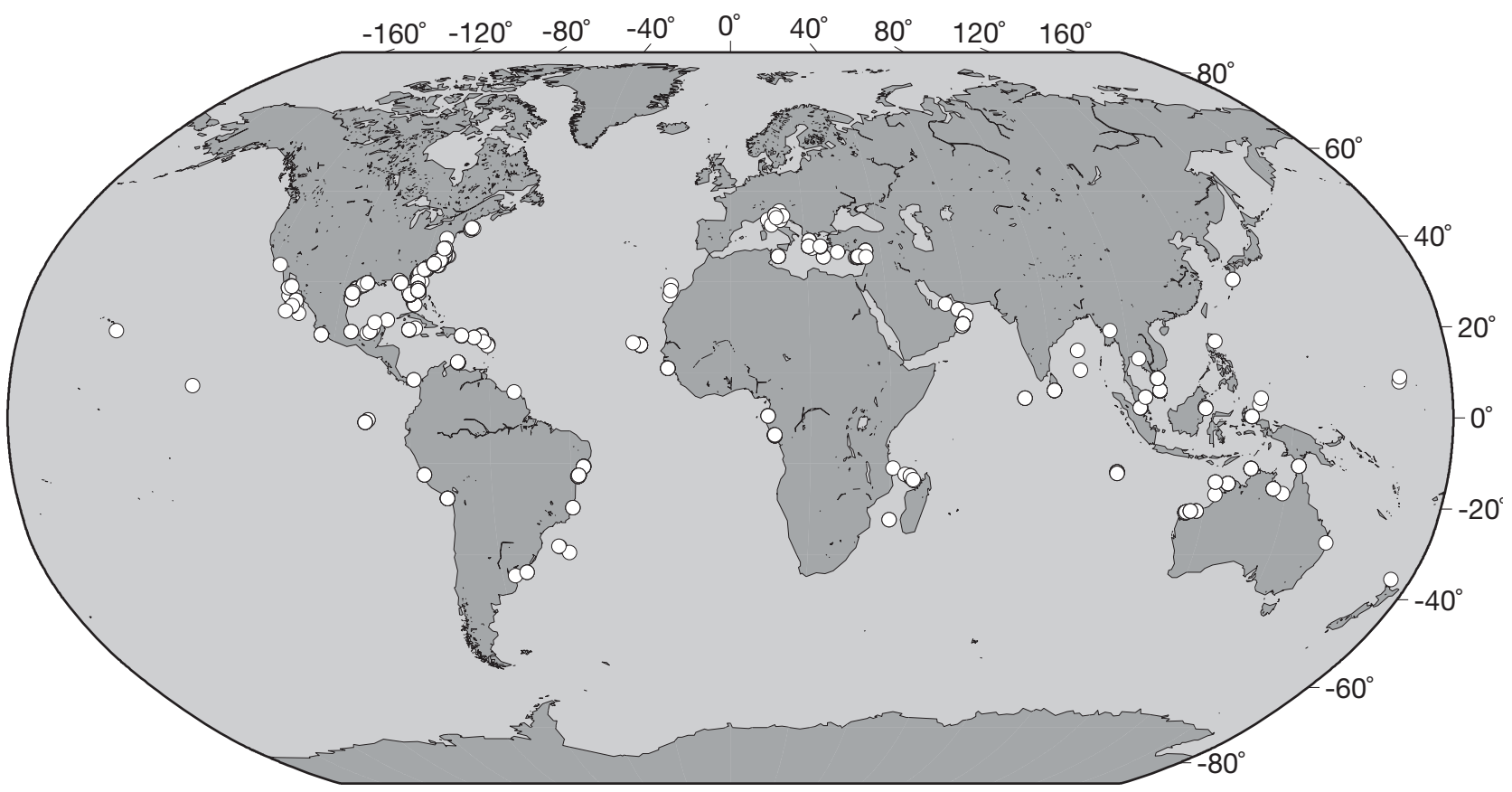

Fig. 3. Spatial footprint of STAT (Satellite Tracking and Analysis Tool, see Coyne \& Godley 2005) turtle tracking projects. Circles denote the launch point of marine turtle tracking with data managed within the STAT system 
on sample sizes $>20$, there is clear need to extend our work into collaborative data-sharing and meta-analyses. It is hoped that innovations such as this nascent clearing house will greatly facilitate needed progress.

\section{A 21ST CENTURY (SATELLITE) TAGGING REFLEX?}

Intrinsically, satellite tracking is exciting and the arguments for potential research dividends outlined above are compelling, while the benefits in terms of public relations and education can also be substantial. The technology has improved and is now available to all workers with access to an online computer and sufficient fiscal resources to buy transmitters, limited consumables and satellite time (ca. US\$5000-10000 per unit depending on transmitter model and longevity). If sea turtle researchers are deploying in the order of 250 to 500 transmitters per year (see Fig. 1d), at the estimated costs above, the costs of the high-tech consumables are between US\$1.25-5.0 million per annum. On top of this are a great deal of associated salary and travel costs that, if they could be calculated, would likely dwarf the above figure. Is sea turtle biology and conservation benefiting enough from this investment? Are we now partaking in a 21st century version of Mrosovsky's (1983) 'tagging reflex'? We must be more self-reflective on a number of issues to ensure that limited resources are used most effectively.

\section{Animal welfare}

Several workers have correctly highlighted the need for a strong ethical standpoint in studies such as animal tracking (Frazier 2000, Hawkins 2004, Wilson \& McMahon 2006, Cooke 2008, this TS). Some questions must be continually asked. Are deployment package compactness and attachment methods sufficient to minimise hydrodynamic drag (cf. Watson \& Granger 1998), weight, buoyancy, physical damage or impingement of natural movement or mating? Are we sure we are not increasing chances of entanglement? Is there potential for magnetic interference e.g. from transmitters placed on the head? We need to share both our failures and successes as we improve our methodologies.

In general, leatherback tracking has proven difficult as one cannot attach transmitters using the standard techniques for hardshell turtles (cf. Renaud et al. 1993); hence the development of a variety of tethers (Morreale et al. 1996), harnesses (Eckert \& Eckert 1986) and direct carapacial attachment procedures (Lutcavage et al. 1999, Fossette et al. 2008, Doyle et al. 2008, this TS). Techniques have clearly improved over the years (for an early example of an excessive transmitter package, see illustration in DuronDufrenne 1987) but given recent concern expressed regarding harnesses (Troëng et al. 2006), it is timely that Fossette et al. (2008) show that, albeit based on a very small sample size, turtles equipped using direct attachment techniques may swim faster and dive deeper than conspecifics equipped with harnesses. Sherrill-Mix \& James (2008, this TS) also investigate potential tagging effects. Given the ever-increasing number of leatherbacks being tracked, this is a topic worthy of much more attention. Although turtle workers have sought to minimize deleterious impacts from the start, we are now entering a phase in our discipline where we can start to empirically test for even quite subtle impacts on our study animals and we must join forces to adequately test for these possibilities.

\section{Scientific rigour}

The topics of experimental design and data analysis and interpretation have been highlighted as concerns that should be given close attention (Frazier 2000). We must constantly ask ourselves whether our sample sizes are sufficient to generate meaningful results. Authors have begun to explicitly target transmission performance and accuracy (Plotkin 1998, Hays et al. $2001 b, 2007$ ) and the array of statistical techniques and treatments to improve the robustness of data interpretation is increasing (Flemming et al. 2006, Jonsen et al. 2006, 2007). There is, however, a clear need for more easily accessible and reliable techniques to help workers describe home ranges and key areas of occupancy that will allow satellite tracking to feed more easily into spatially relevant management. Additionally, tools to allow the quantitative comparison of movement with oceanographic variables need to be refined and made accessible before maximal benefit will be extracted from tracking data.

\section{Is satellite tracking the best technique?}

Although the technique has offered much, it is not a panacea for research needs. It has not yet matured to the point that we can track the smallest of turtles and there is still much to be gained from direct observation, molecular and other forensic methods and oceanographic modeling approaches. For many neritic juveniles, who move short distances for long periods and do not generate many high quality locations (e.g. Godley et al. 2003b), satellite tracking may not be the best 
technique. Indeed, sonic and radio tracking in addition to traditional mark and recapture methods offer greater insight and value for money in some cases (Seminoff et al. 2002, Avens et al. 2003). Standard GPS tracking offers potential but requires reliability of recapture (Schofield et al. 2007). Developing satellitelinked GPS capabilities (Yasuda \& Arai 2005) will hopefully provide significant insights into the movement of all animals, including those that move only short distances without the need for recapture. This is especially true for tags using Fastloc technology that have recently been trialed on loggerhead turtles off North America (M. S. Coyne et al. unpubl.) and shows great promise for the remote gathering of high precision location data. Although not satellite linked, another technique which offers promise is geolocation (GLS) using light levels which, although offering lower spatial resolution and requiring recapture, is relatively inexpensive per animal and may allow the tracking of larger sample sizes (Fuller et al. 2008). Additionally, although currently necessitating recapture, datalogging technologies are now reaching an unparalleled level of breadth, precision and resolution and the advent of the 'Daily Diary' promises to unlock many unknowns about spatial ecology of animals such as turtles (Wilson et al. 2008, this TS).

\section{Publish or be damned!}

We have largely restricted ourselves to the peerreviewed literature in this review although there is an additional wealth of data that has been presented only in arcane technical reports or in symposium proceedings (over 220 non peer-reviewed abstracts in the proceedings of the International Sea Turtle Symposia by 2007; B. J. Godley pers. obs.). The total of papers reviewed here does not compare favourably with this massive total, especially given that many published papers are of the same study individuals featured in previous publications, sometimes repeatedly. Acknowledging that there will always be a delay between tracking and effective publication, it is clear that only the minority of satellite tracking data have been published in the peer-reviewed literature. Although presentation at any venue may be better than no dissemination at all, data that are not fully analysed and presented in the public domain are more liable to be damaged, lost or forgotten and although they can be used by their custodians, this utility is limited. For the greater good, should we (workers and donors) consider time-limited tenure over data before they are shared on the global commons? In the meantime, are your data safe? Are they in a format that will facilitate sharing in the future? In some cases, data may already be lost. Donor organizations and researchers share a responsibility to ensure positive steps are made in this regard.

\section{Seeking outcomes}

This research area offers a great deal of management-relevant information, and is constantly feeding into management plans (e.g. Western Pacific Regional Fishery Management Council 1994, Turtle Expert Working Group 2007) but to date clear documented policy changes as a result of findings are few. For instance, multiple studies have highlighted Nicaragua as holding foraging grounds for adults of 3 species from multiple origins (Troëng et al. 2005a,b, Blumenthal et al. 2006, van Dam et al. 2008), yet largely unmanaged harvesting of adult turtles continues in the coastal waters there (Lagueux 1998). Researchers studying leatherback migration have used satellite tracking data to highlight key areas for leatherback conservation (Eckert 2006, James et al. 2005c) but it is clear that mitigation of threats in these areas is not simple. Perhaps the exception, Shaver \& Rubio (2008) outline how tracking, in addition to nesting and stranding data were instrumental in the development of a timearea fisheries closure in Texas, USA to protect Kemp's ridley turtles.

Much of the sea turtle tracking literature claims to inform conservation but why the apparent lack of clear policy changes? What does it really mean if turtles migrate across international boundaries? What does it mean if there are hotspots for turtles? How can we translate these data into positive outcomes? Are managers and policy makers prepared to make decisions on an $\mathrm{n}=8.5$ (our overall average number of conspecific turtles per study) or on an $\mathrm{n}=9.9$ turtles (our average since 2005)? Are we presenting results in a clearly understandable format and suggesting suitable management changes? Are tracking data perhaps simply one investigative strand that needs to be integrated with multiple lines of evidence to generate a synthetic understanding before the long slog of effecting change can begin? Additionally, unless molecular profiling progresses to a point where individuals can be individually identified for very little cost with no time delay, there is likely always going to be a valid research need to permanently or semi-permanently mark study individuals. This facilitates upfront hypothesis testing (e.g. behaviour of neophytes versus remigrants) and acts as post-hoc backup of identity following loss of satellite tags (Sherrill-Mix \& James 2008).

We suggest that the major scientific breakthroughs in this field are likely to come from increased sample 
size, most easily attained through data-sharing and through inter-disciplinary synergy with others such as ecological modelers, oceanographers, statisticians and and fisheries scientists. Such partnerships will help us to progress from the qualitative to the quantitative with regard to integration of movements with dynamic environmental variables, both physical and anthropogenic e.g. fishing effort. It is time for us all to embrace such approaches, perhaps facilitated through mechanisms such as the clearing house outlined above (Coyne \& Godley 2007). In addition, with appropriate intellectual safeguards, data can (and we suggest should) be shared for management purposes prior to the production of scientific papers (e.g. Turtle Expert Working Group 2007).

In closing, we hope that we have highlighted the obvious need for a clearer strategy to address inadequate sample size and the species, life stage and geographic imbalance of many past studies. We need to participate in a shift in the way we carry out our work for maximal benefit to ensure we can counter any allegations of a 'tagging reflex' (Mrosovsky 1983). Finally, it is our observation that much of the tracking work to date has been funded and acted upon in such a manner that has so far failed to ensure translation of the research into tangible outputs and management benefits. It is the responsibility of all who purport to be carrying out research in the name of sea turtle conservation to work to have our research published, disseminated, built upon and translated into positive conservation action.

Acknowledgements. This paper is an articulation of a plenary presentation at Inter-Research Symposium 1 'Satellite Tracking of Marine Vertebrates' held as part of the 27th Annual Sea Turtle Symposium, Myrtle Beach, SC, USA. We thank the International Sea Turtle Society for hosting the meeting and Prof. Otto Kinne, Prof. Howard Browman and Ms. Penny Kuhn for their support. The authors also thank Philippe Gros and colleagues at CLS for generous sharing of data on numbers of transmitters; Sue Ranger for production of Fig. 2, and the authors, Allen Press, Blackwell, Elsevier and InterResearch Science Publishers for permission to use and modify their original figures; STAT users for allowing us to highlight their deployment locations in the global map; M. Arendt, S. Benson, K. Hart, H. Hatase, M. James, P. Luschi, C. McClellan, K. Mansfield, P. Plotkin, S. Ranger, J. Seminoff, E. Seney, D. Shaver, S. Troëng, T. Tucker, R. van Dam, S. Whiting, and 4 reviewers for Endangered Species Research for highly constructive and useful feedback in discussions or reviews of earlier versions of the manuscript. B.J.G. and A.C.B. are funded by the Darwin Initiative, European Social Fund and Natural Environment Research Council; J.M.B. by a University of Exeter Research Studentship and the Darwin Initiative; M.S.C. by the Large Pelagics Research Center at the University of New Hampshire through National Oceanographic and Atmospheric Agency award NA04NMF4550391; L.A.H. by the Anning Morgan Bursary and a University of Exeter Research Studentship; and M.J.W. by a NERC Research Studentship.

\section{LITERATURE CITED}

Åkesson S, Luschi P, Papi F, Broderick AC, Glen F, Godley BJ, Hays GC (2001) Oceanic long-distance navigation: Do experienced migrants use the Earth's magnetic field? J Navig 54:419-427

Åkesson S, Broderick AC, Glen F, Godley BJ, Luschi P, Papi F, Hays GC (2003) Navigation by green turtles: which strategy do displaced adults use to find Ascension Island? Oikos 103:363-372

Anonymous (1993) Satellites used to study the oceanic migrations of Hawaii's green sea turtles. Mar Turtle Newsl 61:7-9

Anonymous (1994) Long-distance migration of green sea turtles from Pulau Redang tracked by satellites. Mar Turtle Newsl 66:5-7

Argos (1996) User's manual. Argos/CLS, Toulouse

Avens L, Braun-McNeill J, Epperly S, Lohmann KJ (2003) Site fidelity and homing behavior in juvenile loggerhead sea turtles (Caretta caretta). Mar Biol 143:211-220

Baba N, Kiyota M, Suganuma H, Tachikawa H (1992) Research on migratory routes of loggerhead turtles and green turtles by the Argos system. Report on commissioned project for data analysis by scientific observers aboard fishing vessels in 1991. Fisheries Agency of Japan, Tokyo, p 89-99

Balazs GH (1976) Green turtle migrations in the Hawaiian archipelago. Biol Conserv 9:125-140

Baum JK, Myers RA (2004) Shifting baselines and the decline of pelagic sharks in the Gulf of Mexico. Ecol Lett 7:135-145

Beavers SC, Cassano ER (1996) Movements and dive behavior of a male sea turtle (Lepidochelys olivacea) in the eastern tropical Pacific. J Herpetol 30:97-104

Benson SR, Dutton PH, Hitipeuw C, Samber B, Bakarbessy J, Parker D (2007a) Post-nesting migrations of leatherback turtles (Dermochelys coriacea) from Jamursba-Medi, Bird's Head Peninsula, Indonesia. Chelonian Conserv Biol 6:150-154

Benson SR, Kisokau KM, Ambio L, Rei V, Dutton PH, Parker D (2007b) Beach use, internesting movement, and migration of leatherback turtles, Dermochelys coriacea, nesting on the north coast of Papua New Guinea. Chelonian Conserv Biol 6:7-14

Bentivegna F (2002) Intra-Mediterranean migrations of loggerhead sea turtles (Caretta caretta) monitored by satellite telemetry. Mar Biol 141:795-800

Bentivegna F, Valentino F, Falco $P$, Zambianchi E, Hochscheid S (2007) The relationship between loggerhead turtle (Caretta caretta) movement patterns and Mediterranean currents. Mar Biol 151:1605-1614

Block BA (2005) Physiological ecology in the 21st century: advancements in biologging science. Integr Comp Biol 45:305-320

Block BA, Teo SLH, Walli A, Boustany A and others (2005) Electronic tagging and population structure of Atlantic bluefin tuna. Nature 434:1121-1127

Blumenthal JM, Solomon JL, Bell CD, Austin TJ and others (2006) Satellite tracking highlights the need for international cooperation in marine turtle management. Endang Spec Res 2:51-61

Bolker BM, Okuyama T, Bjorndal KA, Bolten AB (2007) Incorporating multiple mixed stocks in mixed stock analysis: 'many-to-many' analyses. Mol Ecol 16:685-695

Bolten AB (2003a) Active swimmers, passive drifters: the oceanic juvenile stage of loggerheads in the Atlantic system. In: Bolton AB, Witheringtoon BE (eds) Loggerhead sea turtles. Smithsonian Instution Press, Washington, DC, p 63-78 
Bolten AB (2003b) Variation in sea turtle life history patterns: neritic vs. oceanic developmental stages. In: Lutz PL, Musick JA, Wyneken J (eds) Biology of sea turtles, Vol II. CRC Press, Boca Raton, FL, p 243-257

Bowen BW, Karl SA (1997) Population genetics, phylogeography, and molecular evolution. In: Lutz PL, Musick JA (eds) The biology of sea turtles. CRC Press, Boca Raton, FL, p 29-50

Bowen BW, Bass AL, Chow SM, Bostron M and others (2004) Natal homing in juvenile loggerhead turtles (Caretta caretta). Mol Ecol 13:3797-3808

Bradshaw CJA, McMahon CR, Hays GC (2007) Behavioral inference of diving metabolic rate in free-ranging leatherback turtles. Physiol Biochem Zool 80:209-219

Broderick AC, Coyne MS, Fuller WJ, Glen F, Godley BJ (2007) Fidelity and overwintering of sea turtles. Proc R Soc Lond B Biol Sci 274:1533-1538

> Cardona L, Revelles M, Carreras C, San Felix M, Gazo M, Aguilar A (2005) Western Mediterranean immature loggerhead turtles: habitat use in spring and summer assessed through satellite tracking and aerial surveys. Mar Biol 147:583-591

Carr A (1987) New perspectives on the pelagic stage of sea turtle development. Conserv Biol 1:103-121

Carr AF, Carr MH, Meylan AB (1978) The ecology and migrations of sea turtles 7: The west Caribbean green turtle colony. Bull Am Mus Nat Hist 162:1-48

Cejudo D, Varo-Cruz N, Liria A, Castillo JJ, Bellido JJ, LópezJurado LF (2006) Transatlantic migration of juvenile loggerhead turtles (Caretta caretta L.) from the Strait of Gibraltar. Mar Turtle Newsl 114:9-11

> Chaloupka M, Parker D, Balazs G (2004a) Modeling postrelease mortality of loggerhead sea turtles exposed to the Hawaii-based pelagic longline fishery. Mar Ecol Prog Ser 280:285-293

> Chaloupka M, Parker D, Balazs G (2004b) Tracking turtles to their death - reply to Hays et al. Mar Ecol Prog Ser 283:301-302

Chan SKF, Chan JK, Lo LT, Balazs GH (2003) Satellite tracking of the post-nesting migration of a green turtle (Chelonia mydas) from Hong Kong. Mar Turtle Newsl 102:2-4

Cheng IJ (2000) Post-nesting migrations of green turtles (Chelonia mydas) at Wan-An Island, Penghu Archipelago, Taiwan. Mar Biol 137:747-754

Cooke SJ (2008) Biotelemetry and biologging in endangered species research and animal conservation: relevance to regional, national, and IUCN Red List threat assessments. Endang Species Res 4:165-185

Coyne MS, Godley BJ (2005) Satellite Tracking and Analysis Tool (STAT): an integrated system for archiving, analyzing and mapping animal tracking data. Mar Ecol Prog Ser 301:1-7

Coyne MS, Godley BJ (2007) Clearing house for satellite tracking data. Mar Turtle Newsl 117:14

Craig P, Parker D, Brainard R, Rice M, Balazs G (2004) Migrations of green turtles in the central South Pacific. Biol Conserv 116:433-438

Dodd CK, Byles R (2003) Post-nesting movements and behavior of loggerhead sea turtles (Caretta caretta) departing from East-Central Florida nesting beaches. Chelonian Conserv Biol 4:530-536

Doyle TK, Houghton JDR, O'Súilleabháin PF, Hobson VJ, Marnell F, Davenport J, Hays GC (2008) Leatherback turtles satellite-tagged in European waters. Endang Species Res 4:23-31

Duron-Dufrenne M (1987) First satellite-based tracking in the Atlantic Ocean of a leatherback turtle Dermochelys cori- acea. CR Acad Sci Paris 304:399-402

Eckert SA (2002) Distribution of juvenile leatherback sea turtle Dermochelys coriacea sightings. Mar Ecol Prog Ser 230:289-293

Eckert SA (2006) High-use oceanic areas for Atlantic leatherback sea turtles (Dermochelys coriacea) as identified using satellite telemetered location and dive information. Mar Biol 149:1257-1267

Eckert SA, Eckert KL (1986) Harnessing leatherbacks. Mar Turtle News 37:1-3

Eckert SA, Sarti L (1997) Distant fisheries implicated in the loss of the world's largest leatherback nesting population. Mar Turtle Newsl 78:2-7

Eckert SA, Bagley D, Kubis S, Ehrhart L, Johnson C, Stewart $\mathrm{K}$, DeFresse D (2006) Internesting and postnesting movements and foraging habitats of leatherback sea turtles (Dermochelys coriacea) nesting in Florida. Chelonian Conserv Biol 5:239-248

Fedak MA (2004) Marine animals as platforms for oceanographic sampling: a 'win/win' situation for biology and operational oceanography. Mem Nat Inst Polar Res 58:133-147

Fedak MA, Lovell P, Grant SM (2001) Two approaches to compressing and interpreting time-depth information as collected by time-depth recorders and satellite-linked data recorders. Mar Mamm Sci 17:94-110

$>$ Ferraroli S, Georges JY, Gaspar P, Maho YL (2004) Endangered species: where leatherback turtles meet fisheries. Nature 429:521-522

Flemming JEM, Field CA, James MC, Jonsen ID, Myers RA (2006) How well can animals navigate? Estimating the circle of confusion from tracking data. Environmetrics $17: 351-362$

Fossette S, Corbel H, Gaspar P, Le Maho Y, Georges JY (2008) An alternative technique for the long-term satellite tracking of leatherback turtles. Endang Species Res 4:33-41

Frazier J (2000) Chelo-telemetry: more on great chelonian taboos. In: Abreu-Grobois FA, Briseno-Duenas R, Marquez $\mathrm{R}$, Sarti L (comps) NOAA Tech Memo NMFSSEFSC-436, Washington, DC, p 97-99

Fuller WJ, Broderick AC, Phillips RA, Silk JRD, Godley BJ (2008) Utility of geolocating light loggers to indicate at-sea movements in sea turtles. Endang Species Res 4:139-146

Gardner TA, Côté I, Gill JA, Grant A, Watkinson AR (2003) Long-term region-wide declines in Caribbean corals. Science 301:958-960

Gaspar P, Georges JY, Fossette S, Lenoble A, Ferraroli S, Le Maho Y (2006) Marine animal behaviour: neglecting ocean currents can lead us up the wrong track. Proc R Soc Lond B Biol Sci 273:2697-2702

Georges J, Fossette S, Billes A, Ferraroli S and others (2007) Meta-analysis of movements in Atlantic leatherback turtles during nesting season: conservation implications. Mar Ecol Prog Ser 338:225-232

Gillespie TW (2001) Remote sensing of animals. Prog Phys Geogr 25:355-362

- Girard C, Sudre J, Benhamou S, Roos D, Luschi P (2006) Homing in green turtles Chelonia mydas: oceanic currents act as a constraint rather than as an information source. Mar Ecol Prog Ser 322:281-289

$>$ Gitschlag GR (1996) Migration and diving beahviour of Kemp's ridley (Garman) sea turtles along the US southeastern Atlantic coast. J Exp Mar Biol Ecol 205:115-135

- Godley BJ, Richardson S, Broderick AC, Coyne MS, Glen F, Hays GC (2002) Long-term satellite telemetry of the movements and habitat utilisation by green turtles in the Mediterranean. Ecography 25:352-362 
Godley BJ, Broderick AC, Glen F, Hays GC (2003a) Post-nesting movements and submergence patterns of loggerhead marine turtles in the Mediterranean assessed by satellite tracking. J Exp Mar Biol Ecol 287:119-134

Godley BJ, Lima E, Åkesson S, Broderick AC and others (2003b) Movement patterns of green turtles in Brazilian coastal waters described by satellite tracking and flipper tagging. Mar Ecol Prog Ser 253:279-288

$>$ Green D (1984) Long-distance movements of Galapagos green turtles. J Herpetol 18:121-130

> Hall MA, Alverson DL, Metuzals KI (2000) By-catch: problems and solutions. Mar Pollut Bull 41:204-219

- Halpin PN, Read AJ, Best BD, Hyrenbach KD and others (2006) OBIS-SEAMAP: developing a biogeographic research data commons for the ecological studies of marine mammals, seabirds, and sea turtles. Mar Ecol Prog Ser 316:239-246

> Hatase H, Sakamoto N (2004) Forage-diving behaviour of adult Japanese female loggerhead turtles (Caretta caretta) inferred from Argos location data. J Mar Biol Assoc UK 84:855-856

Hatase H, Matsuzawa Y, Sakamoto W, Baba N, Miyawaki I (2002a) Pelagic habitat use of an adult Japanese male loggerhead turtle Caretta caretta examined by the Argos satellite system. Fish Sci 68:945-947

Hatase H, Takai N, Matsuzawa Y, Sakamoto W and others (2002b) Size-related differences in feeding habitat use of adult female loggerhead turtles Caretta caretta around Japan determined by stable isotope analyses and satellite telemetry. Mar Ecol Prog Ser 233:273-281

> Hatase H, Sato K, Yamaguchi M, Takahashi K, Tsukamoto K (2006) Individual variation in feeding habitat use by adult female green sea turtles (Chelonia mydas): Are they obligately neritic herbivores? Oecologia 149:52-64

Hawkes LA, Broderick AC, Coyne MS, Godfrey MH and others (2006) Phenotypically linked dichotomy in sea turtle foraging requires multiple conservation approaches. Curr Biol 16:990-995

Hawkes LA, Broderick AC, Coyne MS, Godfrey MH, Godley BJ (2007) Only some like it hot: quantifying the environmental niche of the loggerhead sea turtle. Divers Distrib 13:447-457

Hawkins P (2004) Bio-logging and animal welfare: practical refinements. Mem Nat Inst Polar Res 58:58-68

Hays GC, Webb PI, Hayes JP, Priede IG, French J (1991) Satellite tracking of a loggerhead turtle (Caretta caretta) in the Mediterranean. J Mar Biol Assoc UK 71:743-746

> Hays GC, Luschi P, Papi F, del Seppia C, Marsh R (1999) Changes in behaviour during the inter-nesting period and post-nesting migration for Ascension Island green turtles. Mar Ecol Prog Ser 189:263-273

> Hays GC, Åkesson S, Broderick AC, Glen F and others (2001a) The diving behaviour of green turtles undertaking oceanic migration to and from Ascension Island: dive durations, dive profiles and depth distribution. J Exp Biol 204:4093-4098

Hays GC, Åkesson S, Godley BJ, Luschi P, Santidrian P (2001b) The implications of location accuracy for the interpretation of satellite-tracking data. Anim Behav 61:1035-1040

> Hays GC, Broderick AC, Glen F, Godley BJ, Nichols WJ (2001c) The movements and submergence behaviour of male green turtles at Ascension Island. Mar Biol 139:395-399

Hays GC, Dray M, Quaife T, Smyth TJ and others (2001d) Movements of migrating green turtles in relation to AVHRR derived sea surface temperature. Int J Remote
Sens 22:1403-1411

Hays GC, Broderick AC, Godley BJ, Lovell P, Martin C, McConnell BJ, Richardson S (2002) Biphasal long-distance migration in green turtles. Anim Behav 64:895-898

Hays GC, Åkesson S, Broderick AC, Glen F, Godley BJ, Papi F, Luschi P (2003a) Island-finding ability of marine turtles. Proc R Soc Lond B Biol Sci 270:S5-S7

Hays GC, Broderick AC, Godley BJ, Luschi P, Nichols WJ (2003b) Satellite telemetry suggests high levels of fishinginduced mortality in marine turtles. Mar Ecol Prog Ser 262:305-309

Hays GC, Broderick AC, Godley BJ, Luschi P, Nichols WJ (2004a) Tracking turtles to their death. Mar Ecol Prog Ser 283:299-300

Hays GC, Houghton JD, Isaacs C, Kin RS, Lloyds C, Lovell P (2004b) First records of oceanic dive profiles for leatherback turtles, Dermochelys coriacea, indicate behavioural plasticity associated with long-distance migration. Anim Behav 67:733-743

> Hays GC, Houghton JD, Myers AE (2004c) Pan-Atlantic leatherback turtle movements. Nature 429:522

- Hays GC, Hobson VJ, Metcalfe JD, Righton D, Sims DW (2006) Flexible foraging movements of leatherback turtles across the North Atlantic Ocean. Ecology 87:2647-2656

Hays GC, Bradshaw CJA, James MC, Lovell P, Sims DW (2007) Why do Argos satellite tags deployed on marine animals stop transmitting? J Exp Mar Biol Ecol 349:52-60

Hendrickson JR (1958) The green turtle Chelonia mydas in Malaya and Sarawak. Proc Zool Soc Lond 130:455-535

Hitipeuw C, Dutton PH, Benson SR, Thebu J, Bakarbessy J (2007) Population status and internesting movement of leatherback turtles, Dermochelys coriacea, nesting on the northwest coast of Papua, Indonesia. Chelonian Conserv Biol 6:28-36

Hochscheid S, Bentivegna F, Hays GC (2005) First records of dive durations for a hibernating sea turtle. Biol Lett 1:82-86

$>$ Hochscheid S, Bentivegna F, Hays GC (2007) Overwintering behaviour in marine turtles: dormancy is optional. Mar Ecol Prog Ser 340:287-298

Horrocks JA, Vermeer LA, Krueger B, Coyne M, Schroeder BA, Balazs GH (2001) Migration routes and destination characteristics of post-nesting hawksbill turtles satellitetracked from Barbados, West Indies. Chelonian Conserv Biol 4:107-114

Hughes GR, Luschi P, Mencacci R, Papi F (1998) The 7000-km oceanic journey of a leatherback turtle tracked by satellite. J Exp Mar Biol Ecol 229:209-217

James MC, Eckert SA, Myers RA (2005a) Migratory and reproductive movements of male leatherback turtles (Dermochelys coriacea). Mar Biol 147:845-853

James MC, Myers RA, Ottensmeyer CA (2005b) Behaviour of leatherback sea turtles, Dermochelys coriacea, during the migratory cycle. Proc R Soc Lond B Biol Sci 272:1547-1555

James MC, Ottensmeyer CA, Myers RA (2005c) Identification of high-use habitat and threats to leatherback sea turtles in northern waters: new directions for conservation. Ecol Lett 8:195-201

James MC, Davenport J, Hays GC (2006a) Expanded thermal niche for a diving vertebrate: a leatherback turtle diving into near-freezing water. J Exp Mar Biol Ecol 335:221-226

James MC, Ottensmeyer CA, Eckert SA, Myers RA (2006b) Changes in diel diving patterns accompany shifts between northern foraging and southward migration in leatherback turtles. Can J Zool 84:754-765

Jonsen ID, Myers RA, James MC (2006) Robust hierarchical state-space models reveal diel variation in travel rates of 
migrating leatherback turtles. J Anim Ecol 75:1046-1057 Jonsen ID, Myers RA, James MC (2007) Identifying leatherback turtle foraging behaviour from satellite telemetry using a switching state-space model. Mar Ecol Prog Ser 337:255-264

Keinath JA, Musick JA (1993) Movements and diving behaviour of a leatherback turtle Dermochelys coriacea. Copeia 1993:1010-1017

Kennett R, Munungurritj N, Yunupingu D (2004) Migration patterns of marine turtles in the Gulf of Carpentaria, northern Australia: implications for Aboriginal management. Wildl Res 31:241-248

Lagueux CJ (1998) Marine turtle fishery of Caribbean Nicaragua: human use patterns and harvest trends. $\mathrm{PhD}$ dissertation, University of Florida, Gainesville, FL

Liew HC, Bali J, Chan EH, Braken Q (2000) Satellite tracking of green turtles from the Sarawak Turtle Islands, Malaysia. Mar Turtle Newsl 87:20

Limpus CJ, Limpus DJ (2001) The loggerhead turtle, Caretta caretta, in Queensland: breeding migrations and fidelity to a warm temperate feeding area. Chelonian Conserv Biol 4:142-153

Limpus CJ, Miller JD, Parmenter CJ, Reimer D, McLachlan N, Webb R (1992) Migration of green (Chelonia mydas) and loggerhead (Caretta caretta) turtles to and from Eastern Australian Rookeries. Wildl Res 19:347-358

Luschi P, Papi F, Liew HC, Chan EC, Bonadonna F (1996) Long-distance migration and homing after displacement in the Green turtle (Chelonia mydas): a satellite tracking study. J Comp Physiol [A] 178:447-452

Luschi P, Hays GC, Del Seppia C, Marsh R, Papi F (1998) The navigational feats of green sea turtles migrating from Ascension Island investigated by satellite telemetry. Proc R Soc Lond B Biol Sci 265:2279-2284

Luschi P, Åkesson S, Broderick AC, Glen F, Godley BJ, Papi F, Hays GC (2001) Testing the navigational abilities of ocean migrants: displacement experiments on green sea turtles (Chelonia mydas). Behav Ecol Sociobiol 50:528-534

Luschi P, Hays GC, Papi F (2003a) A review of long-distance movements by marine turtles, and the possible role of ocean currents. Oikos 103:293-302

Luschi P, Hughes GR, Mencacci R, De Bernardi E and others (2003b) Satellite tracking of migrating loggerhead sea turtles (Caretta caretta) displaced in the open sea. Mar Biol 143:793-801

Luschi P, Sale A, Mencacci R, Hughes GR, Lutjeharms JRE, Papi F (2003c) Current transport of leatherback sea turtles (Dermochelys coriacea) in the ocean. Proc R Soc Lond B Biol Sci 270:S129-S132

Luschi P, Lutjeharm JRE, Lambardi R, Mencacci R, Hughes GR, Hays GC (2006) A review of migratory behaviour of sea turtles off Southeastern Africa. S Afr J Sci 102:51-58

Luschi P, Benhamou S, Girard C, Ciccione S, Roos D, Sudre J, Benvenuti S (2007) Marine turtles use geomagnetic cues during open-sea homing. Curr Biol 17:126-133

Lutcavage M, Rhodin AGJ, Sadove SS, Conroy CR (1999) Direct carapacial attachment of satellite tags using orthopedic bioabsorbable mini-anchor screws on leatherback turtles in Culebra, Puerto Rico. Mar Turtle Newsl 95:9-12

McClellan CM, Read AJ (2007) Complexity and variation in loggerhead sea turtle life history. Biol Lett 3:592-594, doi: 10.1098/rsbl.2007.0355

McMahon CR, Hays GC (2006) Thermal niche, large-scale movements and implications of climate change for a critically endangered marine vertebrate. Glob Change Biol 12:1330-1338

McMahon CR, Autret E, Houghton JDR, Lovell P, Myers AE,
Hays GC (2005) Animal-borne sensors successfully capture the real-time thermal properties of ocean basins. Limnol Oceanogr 3:392-398

McMahon CR, Bradshaw CJA, Hays GC (2007) Satellite tracking reveals unusual diving characteristics for a marine reptile, the olive ridley turtle Lepidochelys olivacea. Mar Ecol Prog Ser 329:239-252

Meylan A (1998) Hawksbill turtles still endangered. Nature 391:117

Morreale SJ, Standora EA (2005) Western North Atlantic waters: crucial developmental habitat for Kemp's ridley and loggerhead sea turtles. Chelonian Conserv Biol 4:872-882

Morreale SJ, Standora EA, Spotila JR, Paladino FV (1996) Migration corridor for sea turtles. Nature 384:319-320

Mrosovsky N (1983) Conserving sea turtles. British Herpetological Society, London

Mrosovsky N (1997) IUCN's credibility critically endangered. Nature 389:436

Musick JA, Limpus CJ (1997) Habitat utilisation and migration in juvenile sea turtles. In: Lutz PL, Musick JA (eds) The biology of sea turtles. CRC Press, Boca Raton, FL, p $137-165$

Myers AE, Lovell P, Hays GC (2006) Tools for studying animal behaviour: validation of dive profiles relayed via the Argos satellite system. Anim Behav 71:989-993

Nichols WJ, Resendiz A, Seminoff JA, Resendiz B (2000) Transpacific migration of a loggerhead turtle monitored by satellite telemetry. Bull Mar Sci 67:937-947

NRC (National Research Council, Committee on Sea Turtle Conservation) (1990) Decline of the sea turtles: causes and prevention. National Academy Press, Washington, DC

Pandav B, Choudhury BC (2006) Migration and movement of olive ridleys along the east coast of India. In: Shanker K, Choudhury BC (eds) Marine turtles of the Indian Subcontinent. Universities Press, Hyderabad, p 365-379

Papi F, Luschi P (1996) Pinpointing 'Isla Meta': the case of sea turtles and albatrosses. J Exp Biol 199:65-71

Papi F, Liew HC, Luschi P, Chan EH (1995) Long range migratory travel of a green turtle tracked by satellite: evidence for navigational ability in the open sea. Mar Biol 122:171-175

Papi F, Luschi P, Crosio E, Hughes GR (1997) Satellite tracking experiments on the navigational ability and migratory behaviour of the loggerhead turtle Caretta caretta. Mar Biol 129:215-220

Papi F, Luschi P, Åkesson S, Capogrossi S, Hays GC (2000) Open-sea migration of magnetically disturbed sea turtles. J Exp Biol 203:3435-3443

Pelletier D, Roos D, Ciccione S (2003) Oceanic survival and movements of wild and captive-reared immature green turtles (Chelonia mydas) in the Indian Ocean. Aquat Living Resour 16:35-41

Plotkin PT (1998) Interaction between behavior of marine organisms and the performance of satellite transmitters: a marine turtle case study. Mar Technol Soc J 32:5-9

Plotkin PT (2003) Adult migrations and habitat use. In: Lutz PL, Musick JA, Wyneken J (eds) The biology of sea turtles, Vol II. CRC Press, Boca Raton, FL, p 225-241

Plotkin PT, Spotila JR (2002) Post-nesting migrations of loggerhead turtles Caretta caretta from Georgia, USA: conservation implications for a genetically distinct subpopulation. Oryx 36:396-399

Plotkin PT, Byles RA, Rostal DC, Owens DW (1995) Independent versus socially facilitated oceanic migrations of the olive ridley, Lepidochelys olivacea. Mar Biol 122:137-143 Plotkin PT, Owens DW, Byles R, Patterson RM (1996) Depar- 
ture of male olive ridley turtles (Lepidochelys olivacea) from a nearshore breeding ground. Herpetologica 52:1-7

Polovina JJ, Kobayashi DR, Parker DM, Seki MP, Balazs GH (2000) Turtles on the edge: movement of loggerhead turtles (Caretta caretta) along oceanic fronts, spanning longline fishing grounds in the central North Pacific, 1997-1998. Fish Oceanogr 9:71-82

Polovina JJ, Howell E, Kobayashi DR, Seki MP (2001) The transition zone chlorophyll front, a dynamic global feature defining migration and forage habitat for marine resources. Prog Oceanogr 49:469-483

Polovina JJ, Howell EA, Parker PG, Balazs GH (2003) Divedepth distribution of loggerhead (Caretta caretta) and olive ridley (Lepidochelys olivacea) sea turtles in the central North Pacific: Might deep longline sets catch fewer turtles? Fish Bull (Wash DC) 101:189-193

Polovina JJ, Balazs GH, Howell EA, Parker PG, Seki MP, Dutton PH (2004) Forage and migration habitat of loggerhead (Caretta caretta) and olive ridley (Lepidochelys olivacea) sea turtles in the central North Pacific Ocean. Fish Oceanogr 13:36-51

Polovina JJ, Uchida I, Balazs G, Howell EA, Parker D, Dutton P (2006) The Kuroshio Extension Bifurcation Region: a pelagic hotspot for juvenile loggerhead sea turtles. DeepSea Res II 53:326-339

Renaud ML, Carpenter JA (1994) Movements and submergence patterns of loggerhead turtles (Caretta caretta) in the Gulf of Mexico determined through satellite telemetry. Bull Mar Sci 55:1-15

Renaud ML, Williams JA (2005) Kemp's ridley sea turtle movements and migrations. Chelonian Conserv Biol 4:808-816

Renaud ML, Gitschlag GR, Hale JK (1993) Retention of imitation satellite transmitters fiberglassed to the carapace of sea turtles. Herpetol Rev 24:94-99

Renaud ML, Carpenter JA, Williams JA, Landry AMJ (1996) Kemp's ridley sea turtle (Lepidochelys kempii) tracked by satellite telemetry from Louisiana to nesting beach at Rancho Nuevo, Tamaulipas, Mexico. Chelonian Conserv Biol 2:108-109

Revelles M, Cardona L, Aguilar A, San Félix M, Fernández G (2007a) Habitat use by immature loggerhead sea turtles in the Algerian Basin (western Mediterranean): swimming behaviour, seasonality and dispersal pattern. Mar Biol 151:1501-1515

Revelles M, Isern-Fontanet J, Cardona L, San Félix M, Carreras A, Aguilar A (2007b) Mesoscale eddies, surface circulation and the scale of habitat selection by immature loggerhead sea turtles. J Exp Mar Biol Ecol 347:41-57

Roman J, Palumbi SR (2003) Whales before whaling in the north Atlantic. Science 301:508-510

Sakamoto W, Bando T, Arai N, Baba N (1997) Migration paths of the adult female and male loggerhead turtles Caretta caretta determined through satellite telemetry. Fish Sci 63:547-552

Sale A, Luschi P, Mencacci R, Lambardi P and others (2006) Long-term monitoring of leatherback turtle diving behaviour during oceanic movements. J Exp Mar Biol Ecol 328:197-210

Sasamal SK, Panigraphy RC (2006) Influence of eddies on the migratory routes of the sea turtles of the Bay of Bengal. Indian J Rem Sens 27:3115-3122

Schmid JR, Witzell WN (2006) Seasonal migrations of immature Kemp's ridely turtles (Lepidochelys kempii Garman) along the west coast of Florida. Gulf Mex Sci 2006:28-40

Schofield G, Bishop CM, MacLeon G, Brown P and others (2007) Novel GPS tracking of sea turtles as a tool for con- servation management. J Exp Mar Biol Ecol 347:58-68

Seminoff JA, Dutton PH (2007) Leatherback turtles (Dermochelys coriacea) in the Gulf of California: distribution, demography, and human interactions. Chelonian Conserv Biol 6:137-141

Seminoff JA, Resendiz A, Nichols WJ (2002) Home range of green turtles Chelonia mydas at a coastal foraging area in the Gulf of California, Mexico. Mar Ecol Prog Ser 242: $253-265$

Seminoff JA, Zárate P, Coyne MS, Foley DG, Parker D, Lyon B, Dutton PH (2008) Post-nesting migrations of Galapagos green turtles, Chelonia mydas, in relation to oceanographic conditions of the Eastern Tropical Pacific Ocean: integrating satellite telemetry with remotely-sensed ocean data. Endang Species Res. 4:57-72

Seney E, Landry AM Jr (2008) Satellite telemetry and management of Kemp's ridley sea turtles nesting on the upper Texas coast. Endang Species Res 4:73-84

Shaver DJ, Rubio C (2008) Post-nesting movements of wild and head-started Kemp's ridley sea turtles (Lepidochelys kempii) in the Gulf of Mexico. Endang Spec Res 4:43-55

Shaver DJ, Schroeder BA, Byles RA, Burchfield PM, Pena J, Marquez R, Martinez HJ (2005) Movements and home ranges of adult male Kemp's ridley sea turtles (Lepidochelys kempii) in the Gulf of Mexico investigated by satellite telemetry. Chelonian Conserv Biol 4:817-827

Sherrill-Mix SA, James MC (2008) Evaluating potential tagging effects on leatherback sea turtles. Endang Species Res 4:43-55

Sherrill-Mix SA, James MC, Myers RA (in press) Migration cues and timing in leatherback sea turtles. Behav Ecol

Song X, Wang H, Wang W, Gu H, Chan S, Jiang H (2002) Satellite tracking of post-nesting movements of green turtles Chelonia mydas from the Gangkou Sea Turtle National Nature Reserve, China, 2001. Mar Turtle Newsl 97:8-9

Spring CS, Pike D (1998) Tag recovery supports satellite tracking of a green turtle. Mar Turtle Newsl 82:8

Stoneburner DL (1982) Satellite telemetry of loggerhead sea turtle movement in the Georgia Bight. Copeia 1982: 400-408

Swimmer Y, Brill R, Musyl M (2002) Use of pop-up satellite archival tags to quantify mortality of marine turtles incidentally captured in longline fishing gear. Mar Turtle Newsl 97:3-7

- Swimmer Y, Arauz R, McCracken M, McNaughton L and others (2006) Diving behavior and delayed mortality of olive ridley sea turtles Lepidochelys olivacea after their release from longline fishing gear. Mar Ecol Prog Ser 323:253-261

Timko RE, Kolz AL (1982) Satellite sea turtle tracking. Mar Fish Rev 44:19-24

Troëng S, Dutton PH, Evans D (2005a) Migration of hawksbill turtles Eretmochelys imbricata from Tortuguero, Costa Rica. Ecography 28:394-402

Troëng S, Evans DR, Harrison E, Lagueux CJ (2005b) Migration of green turtles Chelonia mydas from Tortuguero, Costa Rica. Mar Biol 148:435-447

Troëng S, Solano R, Diaz-Merry A, Ordonez J and others (2006) Report on long-term transmitter harness retention by a leatherback turtle. Mar Turtle Newsl 111:6-7

Troëng S, Harrison E, Evans D, De Haro A, Vargas E (2007) Leatherback turtle nesting trends and threats at Tortuguero, Costa Rica. Chelonian Conserv Biol 6:117-122

Turtle Expert Working Group (2007) An assessment of the leatherback turtle population in the Atlantic Ocean. NOAA Tech Rep NMFS-SEFSC-555, NOAA, Washington, DC 
van Dam RP, Diez CE, Balazs GH, Colón LAC, McMillan WO, Schroeder B (2008) Sex-specific migration patterns of hawksbill turtles from Mona Island, Puerto Rico. Endang Spec Res 4:85-94

Wang H, Wang D, Wang W, Song X, Liu Y, Chan K, Gu H (2002) An experimental biotelemetric study based on satellite tracking during post-nesting migrations of green turtles. High Technol Lett 8:16-21

Watson KP, Granger RS (1998) Hydrodynamic effect of a satellite transmitter on a juvenile green turtle (Chelonia mydas). J Exp Biol 201:2497-2505

Western Pacific Regional Fishery Management Council (2004) Management Measures to implement new technologies for the Western Pacific pelagic longline fishery. Western Pacific Regional Fishery Management Council, Honolulu, HI,

Whiting SD, Koch AU (2006) Oceanic movement of a benthic foraging juvenile hawksbill turtle from the Cocos (Keeling) Islands. Mar Turtle Newsl 112:15-16

Whiting S, Hartley S, Lalara S, White D, Bara T, Maminyamunja C, Wurramarrba L (2006) Hawksbill turtle tracking as part of initial sea turtle research and conservation at Groote Eylandt, Northern Australia. Mar Turtle Newsl 114:14-15

Whiting SD, Long JL, Coyne M (2007) Migration routes and foraging behaviour of olive ridley turtles Lepidochelys olivacea in northern Australia. Endang Species Res 3:1-9

Wikelski M, Moskowitz D, Adelman JS, Cochran J, Wilcove
DS, May ML (2006) Simple rules guide dragonfly migration. Biol Lett 2:325-329

Wilson RP, McMahon CR (2006) Measuring devices on wild animals: What constitutes acceptable practice? Front Ecol Environ 4:147-154

Wilson RP, Shepard ELC, Liebsch N (2008) Prying into intimate details of animal lives; why we need a good flight recorder before anything crashes. Endang Species Res 4:123-137

Witt MJ, Broderick AC, Johns DJ, Martin CS, Penrose R, Hoogmoed MS, Godley BJ (2007) Prey landscapes help identify potential foraging habitats for leatherback turtles in the northeast Atlantic. Mar Ecol Prog Ser 337:231-244

Witt MJ, Broderick AC, Coyne M, Formia A and others (in press) Satellite tracking highlights difficulties in the design of effective protected areas for leatherback turtles during the internesting period. Oryx

Yasuda T, Arai N (2005) Fine-scale tracking of marine turtles using GPS-argos PTTs. Zoolog Sci 22:547-553

Yasuda $\mathrm{T}$, Tanaka $\mathrm{H}$, Kittiwattanawong $\mathrm{K}$, Mitamura $\mathrm{H}$, Klom-in W, Arai N (2006) Do female green turtles (Chelonia mydas) exhibit reproductive seasonality in a yearround nesting rookery? J Zool (Lond) 269:451-457

Zbinden JA, Aebischer A, Margaritoulis D, Arlettaz R (2007) Insights into the management of sea turtle internesting area through satellite telemetry. Biol Conserv 137: $157-162$

Appendix 1. Summaries of published studies of satellite tracking in 6 species of marine turtles. Ocean: ocean basin (W: west; C: central; E: eastern); F: adult female; M: adult male; J: juvenile; U: sex/maturity status unknown

\begin{tabular}{|c|c|c|c|c|c|c|c|}
\hline Ocean & Country (state/s) & $\mathrm{F}$ & M & $\mathrm{J}$ & U & Total & Source \\
\hline \multicolumn{8}{|c|}{ Loggerhead turtle Caretta caretta } \\
\hline W Atlantic & USA (Georgia) & 8 & 0 & 0 & 0 & 8 & Stoneburner (1982) \\
\hline W Atlantic & USA (Mississippi) & 1 & 0 & 0 & 0 & 1 & Timko \& Kolz (1982) \\
\hline Mediterranean & Greece & 1 & 0 & 0 & 0 & 1 & Hays et al. (1991) \\
\hline Atlantic & USA (Texas) & 0 & 0 & 4 & 0 & 4 & Renaud \& Carpenter (1994) \\
\hline Indian & South Africa & 4 & 0 & 0 & 0 & 4 & Papi et al. (1997) \\
\hline W Pacific & Japan & 2 & 1 & 0 & 0 & 3 & Sakamoto et al. (1997) \\
\hline E Pacific & Mexico & 0 & 0 & 1 & 0 & 1 & Nichols et al. (2000) \\
\hline E Pacific & High seas & 0 & 0 & 9 & 0 & 9 & Polovina et al. (2000) \\
\hline W Pacific & Australia (Queensland) & 6 & 0 & 0 & 0 & 6 & Limpus \& Limpus (2001) \\
\hline Mediterranean & Italy & 3 & 1 & 0 & 0 & 4 & Bentivegna (2002) \\
\hline W Pacific & Japan & 0 & 1 & 0 & 0 & 1 & Hatase et al. (2002a) \\
\hline W Pacific & Japan & 5 & 0 & 0 & 0 & 5 & Hatase et al. (2002b) \\
\hline W Atlantic & USA (Georgia) & 5 & 0 & 0 & 0 & 5 & Plotkin \& Spotila (2002) \\
\hline W Atlantic & USA (Florida) & 4 & 0 & 0 & 0 & 4 & Dodd \& Byles (2003) \\
\hline Mediterranean & Northern Cyprus & 5 & 0 & 0 & 0 & 5 & Godley et al. (2003a) \\
\hline Indian & South Africa & 11 & 0 & 0 & 0 & 11 & Hays et al. (2003b) \\
\hline Indian & South Africa & 5 & 0 & 0 & 0 & 5 & Luschi et al. (2003b) \\
\hline E Pacific & USA (Hawaii) & 0 & 0 & 0 & 2 & 2 & Polovina et al. (2003) \\
\hline E Pacific & USA (Hawaii) & 0 & 0 & 40 & 0 & 40 & Chaloupka et al. (2004a) \\
\hline W Pacific & Japan & 2 & 0 & 0 & 0 & 2 & Hatase \& Sakamoto (2004) \\
\hline E Pacific & High seas & 3 & 0 & 23 & 0 & 26 & Polovina et al. (2004) \\
\hline Mediterranean & Spain (Balearic Islands) & 0 & 0 & 5 & 0 & 5 & Cardona et al. (2005) \\
\hline Mediterranean & Italy & 0 & 0 & 1 & 0 & 1 & Hochscheid et al. (2005) \\
\hline Mediterranean & Italy, Tunisia & 0 & 0 & 0 & 13 & 13 & Hochscheid et al. (2005) \\
\hline W Atlantic & USA (New York) & 0 & 0 & 3 & 0 & 3 & Morreale \& Standora (2005) \\
\hline W Atlantic & UK (Cayman) & 3 & 0 & 0 & 0 & 3 & Blumenthal et al. (2006) \\
\hline E Atlantic & Spain & 0 & 0 & 2 & 0 & 2 & Cejudo et al. (2006) \\
\hline
\end{tabular}


Appendix 1. continued

\begin{tabular}{|c|c|c|c|c|c|c|c|}
\hline E Atlantic & Cape Verde & 10 & 0 & 0 & 0 & 10 & Hawkes et al. (2006) \\
\hline Indian & South Africa & 8 & 0 & 0 & 0 & 8 & Luschi et al. (2006) \\
\hline W Pacific & High seas & 0 & 0 & 43 & 0 & 43 & Polovina et al. (2006) \\
\hline Mediterranean & Italy & 3 & 1 & 4 & 0 & 4 & Bentivegna et al. (2007) \\
\hline Mediterranean & Northern Cyprus & 10 & 0 & 0 & 0 & 10 & Broderick et al. (2007) \\
\hline Mediterranean & Cyprus & 2 & 0 & 0 & 0 & 2 & Fuller et al. (2008) \\
\hline W Atlantic & USA (North Carolina) & 12 & 0 & 0 & 0 & 12 & Hawkes et al. (2007) \\
\hline W Atlantic & USA (North Carolina) & 0 & 0 & 30 & 0 & 30 & McClellan \& Read (2007) \\
\hline Mediterranean & Spain (Balearic Islands) & 0 & 0 & 10 & 0 & 10 & Revelles et al. (2007a) \\
\hline Mediterranean & Spain (Balearic Islands) & 0 & 0 & 10 & 0 & 10 & Revelles et al. (2007b) \\
\hline Mediterranean & Greece & 6 & 0 & 0 & 0 & 6 & Zbinden et al. (2007) \\
\hline \multicolumn{8}{|c|}{ Green turtle Chelonia mydas } \\
\hline E Pacific & USA (Hawaii) & 3 & 0 & 0 & 0 & 3 & Anonymous (1993) \\
\hline Indian & Malaysia & 1 & 0 & 0 & 0 & 1 & Anonymous (1994) \\
\hline W Pacific & Malaysia & 1 & 0 & 0 & 0 & 1 & Papi et al. (1995) \\
\hline W Pacific & Malaysia & 4 & 0 & 0 & 0 & 4 & Luschi et al. (1996) \\
\hline C Atlantic & UK (Ascension) & 6 & 0 & 0 & 0 & 6 & Luschi et al. (1998) \\
\hline Indian & Australia (West Australia) & 1 & 0 & 0 & 0 & 1 & Spring \& Pike (1998) \\
\hline C Atlantic & UK (Ascension) & 11 & 0 & 0 & 0 & 11 & Hays et al. (1999) \\
\hline W Pacific & Taiwan & 8 & 0 & 0 & 0 & 8 & Cheng (2000) \\
\hline Indian & Malaysia & 8 & 0 & 0 & 0 & 8 & Liew et al. (2000) \\
\hline C Atlantic & UK (Ascension) & 15 & 0 & 0 & 0 & 15 & Papi et al. (2000) \\
\hline C Atlantic & UK (Ascension) & 15 & 0 & 0 & 0 & 15 & Åkesson et al. (2001) \\
\hline C Atlantic & UK (Ascension) & 0 & 2 & 0 & 0 & 2 & Hays et al. (2001a) \\
\hline C Atlantic & UK (Ascension) & 1 & 0 & 0 & 0 & 1 & Hays et al. (2001b) \\
\hline C Atlantic & UK (Ascension) & 12 & 0 & 0 & 0 & 12 & Hays et al. (2001c) \\
\hline C Atlantic & UK (Ascension) & 5 & 0 & 0 & 0 & 5 & Hays et al. (2001d) \\
\hline C Atlantic & UK (Ascension) & 18 & 0 & 0 & 0 & 18 & Luschi et al. (2001) \\
\hline Mediterranean & North Cyprus & 6 & 0 & 0 & 0 & 6 & Godley et al. (2002) \\
\hline C Atlantic & UK (Ascension) & 7 & 0 & 0 & 0 & 7 & Hays et al. (2002) \\
\hline W Pacific & China (Guangdong) & 3 & 0 & 0 & 0 & 3 & Song et al. (2002) \\
\hline W Pacific & China (Guangdong) & 3 & 0 & 0 & 0 & 3 & Wang et al. (2002) \\
\hline C Atlantic & UK (Ascension) & 18 & 0 & 0 & 0 & 18 & Åkesson et al. (2003) \\
\hline W Pacific & China (Hong Kong) & 1 & 0 & 0 & 0 & 1 & Chan et al. (2003) \\
\hline W Atlantic & Brazil (Ceara) & 2 & 0 & 6 & 0 & 8 & Godley et al. (2003b) \\
\hline C Atlantic & UK (Ascension) & 6 & 0 & 0 & 0 & 6 & Hays et al. (2003a) \\
\hline Indian & $\begin{array}{l}\text { France (La Reunion, } \\
\text { Tromelin, Moheli) }\end{array}$ & 2 & 0 & 6 & 0 & 8 & Pelletier et al. (2003) \\
\hline $\begin{array}{l}\text { Mediterranean, } \\
\text { W Pacific, E Pacific, } \\
\text { C Atlantic }\end{array}$ & $\begin{array}{l}\text { Cyprus, Malaysia, } \\
\text { Mexico, UK (Ascension) }\end{array}$ & 31 & 0 & 0 & 0 & 31 & Hays et al. (2003b) \\
\hline W Pacific & American Samoa & 7 & 0 & 0 & 0 & 7 & Craig et al. (2004) \\
\hline W Pacific & Australia (Northern Territory) & ) 20 & 0 & 0 & 0 & 20 & Kennett et al. (2004) \\
\hline E Pacific & Costa Rica & 0 & 0 & 1 & 0 & 1 & Swimmer et al. (2006) \\
\hline W Atlantic & Costa Rica & 10 & 0 & 0 & 0 & 10 & Troëng et al. (2005b) \\
\hline Indian & Thailand & 1 & 0 & 0 & 0 & 1 & Yasuda \& Arai (2005) \\
\hline W Atlantic & UK (Cayman Islands) & 7 & 0 & 0 & 0 & 7 & Blumenthal et al. (2006) \\
\hline Indian & France (Europa) & 3 & 0 & 0 & 0 & 3 & Girard et al. (2006) \\
\hline W Pacific & Japan & 4 & 0 & 0 & 0 & 4 & Hatase et al. (2006) \\
\hline Indian & Thailand & 7 & 0 & 0 & 0 & 7 & Yasuda et al. (2006) \\
\hline Mediterranean & North Cyprus & 10 & 0 & 0 & 0 & 10 & Broderick et al. (2007) \\
\hline Indian & France (Mayotte) & 20 & 0 & 0 & 0 & 20 & Luschi et al. (2007) \\
\hline E Pacific & Ecuador(Galapagos) & 12 & 0 & 0 & 0 & 12 & Seminoff et al. (2008) \\
\hline Mediterannean & Cyprus & 4 & 0 & 0 & 0 & 4 & Fuller et al. (2008) \\
\hline \multicolumn{8}{|c|}{ Leatherback turtle Dermochelys coriacea } \\
\hline W Atlantic & France (French Guiana) & 1 & 0 & 0 & 0 & 1 & Duron-Dufrenne (1987) \\
\hline W Atlantic & USA (USVI) & 1 & 0 & 0 & 0 & 1 & Keinath \& Musick (1993) \\
\hline E Pacific & Costa Rica & 8 & 0 & 0 & 0 & 8 & Morreale et al. (1996) \\
\hline E Pacific & Mexico (Michoacán) & 9 & 0 & 0 & 0 & 9 & Eckert \& Sarti (1997) \\
\hline Indian, E Atlantic & South Africa (KwaZulu-Natal & 1) 1 & 0 & 0 & 0 & 1 & Hughes et al. (1998) \\
\hline Indian & South Africa (KwaZulu-Natal & 1) 3 & 0 & 0 & 0 & 3 & Luschi et al. (2003b) \\
\hline E Pacific, Indian & Mexico, South Africa & 8 & 0 & 0 & 0 & 8 & Hays et al. (2003b) \\
\hline W Atlantic & France (French Guiana) & 12 & 0 & 0 & 0 & 12 & Ferraroli et al. (2004) \\
\hline
\end{tabular}


Appendix 1. continued

\begin{tabular}{|c|c|c|c|c|c|c|c|}
\hline W Atlantic & Grenada & 4 & 0 & 0 & 0 & 4 & Hays et al. (2004a) \\
\hline W Atlantic & Grenada & 9 & 0 & 0 & 0 & 9 & Hays et al. (2004b) \\
\hline W Atlantic & Puerto Rico & 3 & 0 & 0 & 0 & 3 & Lutcavage et al. (1999) \\
\hline W Atlantic & Canada & 0 & 11 & 0 & 0 & 11 & James et al. (2005a) \\
\hline W Atlantic & Canada & 9 & 3 & 3 & 0 & 15 & James et al. (2005b) \\
\hline W Atlantic & Canada & 21 & 11 & 6 & 0 & 38 & James et al. (2005c) \\
\hline W Atlantic & Grenada & 6 & 0 & 0 & 0 & 6 & McMahon et al. (2005) \\
\hline W Atlantic & Trinidad and Tobago & 9 & 0 & 0 & 0 & 9 & Eckert (2006) \\
\hline W Atlantic & USA (Florida) & 10 & 0 & 0 & 0 & 10 & Eckert et al. (2006) \\
\hline W Atlantic & Canada (Nova Scotia) & 0 & 0 & 0 & 0 & 3 & Flemming et al. (2006) \\
\hline W Atlantic & France (French Guiana) & 1 & 0 & 0 & 0 & 1 & Gaspar et al. (2006) \\
\hline W Atlantic & Grenada & 9 & 0 & 0 & 0 & 9 & Hays et al. (2006) \\
\hline W Atlantic & Canada & 3 & 2 & 0 & 0 & 5 & James et al. (2006a) \\
\hline W Atlantic & Canada & 0 & 0 & 0 & 15 & 15 & James et al. (2006b) \\
\hline W Atlantic & Canada & 8 & 3 & 3 & 0 & 14 & Jonsen et al. (2006) \\
\hline W Atlantic & Grenada & 9 & 0 & 0 & 0 & 9 & McMahon \& Hays (2006) \\
\hline Indian & South Africa (KwaZulu-Natal) & 4 & 0 & 0 & 0 & 4 & Sale et al. (2006) \\
\hline W Atlantic & Grenada & 1 & 0 & 0 & 0 & 1 & Myers et al. (2006) \\
\hline Indian & South Africa & 11 & 0 & 0 & 0 & 11 & Luschi et al. (2006) \\
\hline W Atlantic & Grenada & 9 & 0 & 0 & 0 & 9 & Bradshaw et al. (2007) \\
\hline W Pacific & Indonesia & 9 & 0 & 0 & 0 & 9 & Benson et al. (2007a) \\
\hline W Pacific & Papua New Guinea & 19 & 0 & 0 & 0 & 19 & Benson et al. (2007b) \\
\hline W Pacific & Indonesia & 10 & 0 & 0 & 0 & 10 & Hitipeuw et al. (2007) \\
\hline E Pacific & USA (California) & 0 & 1 & 0 & 0 & 1 & Seminoff \& Dutton (2007) \\
\hline W Atlantic & France (French Guiana) & 5 & 0 & 0 & 0 & 5 & Fossette et al. (2008) \\
\hline W Atlantic, E Atlantic & $\begin{array}{l}\text { France (French Guiana), } \\
\text { Gabon, Grenada, Suriname }\end{array}$ & 37 & 0 & 0 & 0 & 37 & Georges et al. (2007) \\
\hline W Atlantic & Canada & 0 & 0 & 0 & 5 & 5 & Jonsen et al. (2007) \\
\hline W Atlantic & Costa Rica & 2 & 0 & 0 & 0 & 2 & Troëng et al. (2007 \\
\hline E Atlantic & Gabon & 7 & 0 & 0 & 0 & 7 & Witt et al. (in press) \\
\hline W Atlantic & Eire & 1 & 1 & 0 & 0 & 2 & Doyle et al. (2008) \\
\hline W Atlantic & Canada & 20 & 8 & 14 & 0 & 42 & Sherrill-Mix \& James (2008) \\
\hline \multicolumn{8}{|c|}{ Hawksbill turtle Eretmochelys imbricata } \\
\hline W Atlantic & Barbados & 4 & 0 & 0 & 0 & 4 & Horrocks et al. (2001) \\
\hline W Atlantic & Costa Rica & 2 & 0 & 0 & 0 & 2 & Troëng et al. (2005a) \\
\hline na(captivity) & Thailand & 0 & 0 & 2 & 0 & 2 & Yasuda \& Arai (2005) \\
\hline Indian & Cocos Islands & 0 & 0 & 1 & 0 & 1 & Whiting \& Koch (2006) \\
\hline W Pacific & Australia (Northern Territory) & 2 & 0 & 0 & 0 & 2 & Whiting et al. (2006) \\
\hline W Atlantic & Puerto Rico & 7 & 8 & 0 & 0 & 15 & van Dam et al. (2008) \\
\hline \multicolumn{8}{|c|}{ Kemp's ridley turtle Lepidochelys kempii } \\
\hline W Atlantic & USA (Louisiana) & 1 & 0 & 0 & 0 & 1 & Renaud et al. (1996) \\
\hline W Atlantic & USA (Georgia) & 1 & 0 & 0 & 0 & 1 & Gitschlag et al. (1996) \\
\hline W Atlantic & $\begin{array}{l}\text { USA (Texas, Louisiana, } \\
\text { North Carolina) }\end{array}$ & 0 & 0 & 0 & 57 & 57 & Renaud \& Williams (2005) \\
\hline W Atlantic & Mexico (Tamaulipas) & 0 & 11 & 0 & 0 & 11 & Shaver et al. (2005) \\
\hline W Atlantic & USA (New York) & 0 & 0 & 12 & 0 & 12 & Morreale \& Standora (2005) \\
\hline W Atlantic & USA (Florida) & 0 & 0 & 6 & 0 & 6 & Schmid \& Witzell (2006) \\
\hline W Atlantic & USA (Texas) & 28 & 0 & 0 & 0 & 28 & Shaver \& Rubio (2008) \\
\hline W Atlantic & USA (Texas) & 6 & 0 & 0 & 0 & 6 & Seney \& Landry (2008) \\
\hline \multicolumn{8}{|c|}{ Olive ridley turtle Lepidochelys olivacea } \\
\hline E Pacific & Costa Rica & 12 & 0 & 0 & 0 & 12 & Plotkin et al. (1995) \\
\hline E Pacific & High seas & 0 & 1 & 0 & 0 & 1 & Beavers \& Cassano (1996) \\
\hline E Pacific & Costa Rica & 0 & 11 & 0 & 0 & 11 & Plotkin et al. (1996) \\
\hline E Pacific & Costa Rica & 21 & 0 & 0 & 0 & 21 & Plotkin (1998) \\
\hline E Pacific & USA (Hawaii), Costa Rica & 0 & 0 & 8 & 0 & 8 & Swimmer et al. (2002) \\
\hline E Pacific & USA (Hawaii) & 0 & 0 & 0 & 2 & 2 & Polovina et al. (2003) \\
\hline C Pacific & High Seas & 0 & 0 & 10 & 0 & 10 & Polovina et al. (2004) \\
\hline E Pacific & Costa Rica & 0 & 0 & 1 & 13 & 14 & Swimmer et al. (2006) \\
\hline Indian & India (Orissa) & 4 & 0 & 0 & 0 & 4 & Pandav \& Choudhury (2006) \\
\hline Indian & India (Orissa) & 4 & 0 & 0 & 0 & 4 & Sasamal \& Panigraphy (2006) \\
\hline W Pacific & Australia (Northern Territory) & 4 & 0 & 0 & 0 & 4 & McMahon et al. (2007) \\
\hline W Pacific & Australia (Northern Territory) & 8 & 0 & 0 & 0 & 8 & Whiting et al. (2007) \\
\hline
\end{tabular}

